\title{
LAENAMINE, ANALOOGIA JA TÄHENDUS LIITNIMISÕNAMOODUSTUSES ${ }^{1}$
}

\author{
MAIRE RAADIK
}

\begin{abstract}
Annotatsioon. Kirjutises vaadeldakse nominatiivse ja genitiivse liitumise vahekorda liitsubstantiivides. Analüüsi aluseks on Eesti Keele Instituudi keelenõuandmebaasi küsimused nominatiivse ja genitiivse liitumise kohta, mis on esitatud 1990. aastate keskpaigast kuni 2020. aastani (kokku u 3300 küsimust). Vaatlus ei hõlma $s$-sõnade liitumist. Keelenõuandmebaasi materjali kõrvutatakse õigekeelsussõnaraamatu normingutega, mis on olnud üks küsimustele vastamise aluseid, ning normingute ja nõuannete vastavust tegelikule kasutusele üldkeeles uuritakse eesti keele ühendkorpuse 2019 najal. Lähemalt käsitletakse liitsubstantiivide võõr- ja omasõnalise esikomponendi liitumist, vaadeldes nii suuremaid sõnarühmi kui ka probleemsemaid üksiksõnu, ning liitumisnormingute kujunemist ja kasutusandmetest lähtuvat teisenemist õigekeelsussõnaraamatus, eriti vahenditähendust märkiva täiendsõnaga liitsubstantiivide näitel.
\end{abstract}

Võtmesõnad: liitsubstantiiv, nominatiivne ja genitiivne liitumine, oskuskeel, üldkeel, keelekorraldus, õigekeelsussõnaraamat

\section{Sissejuhatus}

Liitsõna täiendosa vorm võib oleneda mitmest asjaolust: sõna tähendusest, tarvituseletuleku ajast (varem keelde tulnud sõnad on suuremal määral liitunud nominatiivselt kui hilisemad), päritolust (võõrsõnades esineb tugev tendents liituda nominatiivselt), samuti võidakse mõne põhisõnaga seoses eelistada üht või teist liitumist. Eesti keelele on omane moodustada liitsõnu pigem genitiivse kui nominatiivse liitumise teel ning vahetegemine nominatiivse ja genitiivse liitumise vahel on sageli tuhmunud. Genitiivi üldistumist soodustavate põhjustena on nimetatud genitiivi lõpu $-n \mathrm{kadu}$,

${ }^{1}$ Kirjutis on valminud riikliku programmi „Eesti keel ja kultuur digiajastul“ projekti „Eesti keele sõnavara ja korraldus: deskriptiivne ja preskriptiivne vaatenurk“ (EKKD64) raames. 
lõppvokaali kadu, nendest tingitud mitmesuguseid analoogiaid ning keele kõlavuse ja sujuvuse taotlust (Aavik 1914: 12; Veski 1957: 21; Riikoja 1962: 614). Teisiti on lugu soome keeles, kus on jäänud domineerima varasem, st nominatiivne liitumisviis. Genitiivi levimiseks pole olnud põhjust, sest soome keeles on püsinud nii lõppvokaal kui ka genitiivi lõpp $-n$, mistõttu vahe nominatiivi ja genitiivi vahel on alati olemas. Eelistades liita täiendosa vastavalt kas genitiivselt või nominatiivselt, on mõlemad keeled saanud hoiduda sõnade liitmisel konsonantide kuhjumisest (vrd eesti tuhkkolle ja tuhakolle, soome tuhkapesä ja tuhanpesä). Nooreestlaste algatusel hakati XX sajandi algul ka Eestis propageerima nominatiivset liitumist, Soomes on sama moodi propageeritud genitiivset (Kolehmainen 2011).

Nominatiivse liitumise teadlikumat ja sihipärasemat rakendamist on seostatud eeskätt Johannes Voldemar Veski ja Johannes Aaviku nimega, mõlemad toetusid Ferdinand Johann Wiedemanni kogutud ainestikule. Veski sõnastas 1913. ja 1914. aasta kirjutistes üldpõhimõtte, mille kohaselt liidetakse liitsõna täiendosa nominatiivselt, kui „,kokkuliidetavad nimisõnad umbes ühesugust sisu avaldavad (coordinaatio)“, genitiivselt aga siis, kui „mõisted sisuliselt teineteisest olenevad (subordinatio)“ (Veski 1914: 184). Aavik pühendas nominatiivsele liitumisele terve raamatu (1914), fikseerides nimetavalise liitumise sisupiirkonnad. Nimetavas käändes täiendsõna võib märkida a) ainet, materjali, b) asja kuju, välimust (konkreetsed mõisted), c) kohta, d) otstarvet ja e) abinõu ja viisi (abstraktmõisted). Tõdedes, et keeles ei ole „loogikal ja mõistete ratsionaalsel äramääramisel kaugeltki seda tähtsust, mida harilikult oletatakse; päämõju on siin sagedasti vormilisel küljel, mille analoogia oma enamuse tõttu ka need nähtused enda alla kisub, mis sinna õiguse poolest ei kuuluks", soovitas ta siiski päästa mis päästa annab ehk kultiveerida nominatiivi seal, kus see keeletunnet liigselt ei haava. Nominatiivsete liitsõnade paremuseks pidas Aavik nende omapära, lühidust (otstarbekohasus) ja ilu (esteetiline printsiip). (Aavik 1914: 4-10, 16-17)

Veski on nominatiivse liitumise küsimusi põhjalikumalt käsitlenud 1957. aasta kirjutises, kus ta muu hulgas polemiseeris Erich Raieti, Ernst Nurme ja Elmar Elistoga, kes Veski arvates tähtsustasid küll keeles valitsevat rahvapärasust, traditsiooni, keelepraktikat, kuid ei pidanud silmas järjekindlust, reeglipärasust, analoogilisust. Veski nägi nii rahva- kui ka reeglipärasusel üksikult võetuna puudujääke, mida ainult koosrakendamise 
teel suudetakse kõrvaldada. (Veski 1957: 21 jj) Toetudes rahvakeelest pärit näidetele, kus nominatiivsel ja genitiivsel liitumisel on eri sisu (nt metsmees ja metsamees, käsikiri ja käekiri), taotles ta sellise eristuse järjekindlat rakendamist kirjakeeleski, olenemata ka täiendsõnaks oleva nimisõna tüübist, vrd nt kuderavi ja koeravi, uniravi ja uneravi, tõkepuu ja tõkkepuu, juhtgrupp ja juhigrupp, taimhaigused ja taimehaigused, vorstmürgistus ja vorstimürgistus (Veski 1954: 2).

Liitsõnade moodustamist kirjakeeles ja murretes on võrdlevalt uurinud Elli Riikoja, kes 1956-1962 ilmunud artiklisarjas ning 1960. aastal kaitstud väitekirjas ,Eesti keele nimisõnade nominatiivse liitumise reeglite rahvakeelne alus" analüüsis vormilisi ja tähenduslikke tegureid, mis mõjutavad liitumistüübi valikut murdekeeles. Riikoja uurimustest on kasvanud välja seisukoht, mille kohaselt ei määra täiendosa vorm kummalgi juhul, ei nominatiivse ega ka genitiivse liitumise korral, otseselt ära liitsõna täpsemat tähendust (vt EKG: 462-463, samuti Kasik 2015: 297). Teadlikult püütakse sellist eristust rakendada siiski oskuskeeles (vt nt tehnikakeele kohta Jürgenson 1968, linnunimetuste kohta Leibak 2001).

Olukorras, kus tuleb pidevalt luua uusi sõnu, sh oskussõnu, on ka vaja põhimõtteid nende moodustamiseks (vt ka Tauli 1968: 152-153). Tõenäoliselt põhjalikema loetelu nominatiivse ja genitiivse liitumise sisurühmadest on andnud 1967 ilmunud Tartu ülikooli „Eesti keele grammatika“ liitsõnavihik, milles on üles loetud 16 nominatiivse liitumise tähendusrühma. Neist on omakorda välja sõelutud viis üldisemat: 1) ainet ja koosnevust märkivad rühmad, 2) põhisõna esinemiskuju või sisulist olemust näitavad rühmad, 3) täiendsõna tõstab esile olulise, silmatorkava tunnuse, 4) täiendsõna märgib olulist esinemiskohta või -aega, 5) täiendsõna märgib kehaliiget või vahendit, mille abil midagi tehakse. (Kask 1967: 17-30) 1995 ilmunud „Eesti keele grammatika“ toob kindla nominatiivse liitumise piirkonnana esile üksnes sõnu, kus täiendsõna märgib põhiosaga nimetatud eseme või olendi ehituslikult või funktsionaalselt olulist tunnust, nt klahvpill, lehtpuu, ketassaag, kaunvili, tornmaja, ahelpiste. Tunnuse esiletõst hõlmab ka juhtumeid, kus liitsõna täiendosa märgib seda, kes või mis põhisõnaga nimetatu on, nt meesõpetaja, lapsnäitleja, agressorriik (EKG: 462-463), Reet Kasiku käsitluses on need samastava seosega liitsõnad, nt poisslaps, lapssõdur, kahjurputukas, pilootprojekt, doonorriik (Kasik 2015: 297). Genitiivse liitumise piirkonnana on nimetatud possessiivse ja objektitähendusega nimetusi (EKG 1995: 463). 
Kirjutises uuritakse, kuidas suhestuvad ÕSis esitatud liitumisnormingud Eesti Keele Instituudi keelenõuandmebaasi materjali ja korpuse sagedusandmetega. Uurimus on välja kasvanud Eesti Keele Instituudis koostatava ühendsõnastiku täiendamisest ÕSi soovitusi puudutava teabega, mis on tinginud vajaduse vaadata ühendsõnastiku töörühma ühiste arutelude käigus läbi keelekorralduse põhimõtted, arvestades tegelikku keelekasutust ja uusi digitaalseid võimalusi, ning neid põhimõtteid uuendada. Keelenõumaterjal hõlmab u 3300 küsimust, mis on liitsubstantiivide nominatiivse ja genitiivse liitumise kohta esitatud 1990. aastate keskpaigast kuni 2020. aastani. 1970. aastate liitumisküsimustest on ülevaate andnud Tiiu Erelt (1976: 717 jj). Siinne analüüs ei hõlma $s$-lõpuliste sõnade liitumist, millest on kirjutanud Sirje Mäearu (2016). Sõnade esinemust üldkeeles on uuritud eesti keele ühendkorpuse 2019 najal 2020. aasta novembris ja 2021. aasta jaanuaris. ÕS, kui selle juures pole viidatud muud aastaarvu, on ÕS 2018.

\section{1. ÕSi liitumissoovitused}

Esimene õigekeelsussõnaraamat, 1918. aastal ilmunud „Eesti keele õigekirjutuse-sõnaraamat", liitsõnu ei sisalda, kuid järgmises, 1925-1937 ilmunud ja põhiosas Veski toimetatud kolmeköitelises ,Eesti õigekeelsuse-sõnaraamatus“ (EÕS) on neid juba rikkalik valik. Nominatiivselt on muu hulgas liidetud täiendsõnu, mis märgivad ainet (nt roogmatt, siidkleit, õlgkatus), vahendit (elekterküte, gaasküte, kõhthingamine), olulist tunnust (mürkaine, -madu, -seen, suhkur-, unitõbi), eseme või nähtuse esinemiskuju (hoogvihm). Mõne ainesõna puhul on antud rööpvorme, mis on hinnatud kas võrdväärseks, nt paekallas, -põhi, -sein = paaskallas, -põhi, -sein, või on üht teisele eelistatud, nt genitiivse täiendsõnaga liitsõnade lumekannike(ne) ja lumemees asemel on soovitatud nominatiivse täiendsõnaga kujusid lumikelluke ja lumimees (kuid siiski genitiivne lumememm). Ehkki Veski taotles ranget süsteemikindlust, minnes kohati vastuollu ühiskeele tarvitusega, ei ole ta EÕSis (ega ka „Eesti entsüklopeedias“", mida ta toimetas) nt kõiki vahendit märkiva täiendsõnaga liitsõnu siiski nominatiivse liitumise alla painutanud, genitiivsena on esitatud gaasivalgustus, alkoholimürgitus, pliiatsijoonistus, postisaadetis, postiühendus, masinakirjutaja, masinakirjutus, masinaladu, masinakudumine, kõhurääkija, kõhurääkimine, rongisõit, nõelapiste, kepiharjutus, röntgenikiiritus jt (Nurm 1971: 168). Elmar Muugi „Väike õigekeelsus-sõnaraamat“ (1. tr 1933, 7. tr 1940) 
rakendab vahendisõnades, täpsemini põhjusliku täiendosaga liitsõnades kohati isegi suuremat süsteemsust, esitades nominatiivse täiendsõnaga nt vigastusi (elektervigastus) ja mürgistusi (alkohol-, arseen-, elavhõbe-, gaasmürgistus).

Veski-Muugi reegli järgi tuleb juhul, kui liitsõna põhisõnaks on deverbaal, rakendada vahendit märkiva täiendsõna nominatiivset liitumist (elektervalgustus, gaasküte, aurkümblus), muil juhtumeil on aga peetud õigeks genitiivset liitumist (elektrivalgus, gaasipliit, aurukatel) (Nurm 1971: 171). Vahendisuhte väljendamisele just nominatiivse täiendsõnaga pani aluse Aavik (1914: $19 \mathrm{jj}$ ), lähtudes mh vesiveski sõnast, tänapäevase sõnastuse andis reeglile Muuk (Muuk, Tedre 1931: 41). Enamasti puudutab vahenditähendus (uuemaid) termineid, rahvakeeles on selliseid sõnu suhteliselt väike rühm (Riikoja 1958: 287). Vaidlusi ongi põhjustanud see, kas väike rahvakeelne rühm annab alust laiendada vahendisõnades genitiivset liitumist ka kirjakeelde, eeskätt oskuskeelde, või tohiks oskuskeeles taotleda suuremat süsteemsust ehk liita vahendisõnu nominatiivselt.

Kahes Muugi VÕSile järgnenud ÕSis, s.o „Väikeses õigekeelsuse sõnaraamatus“ (1953) ja „Õigekeelsuse sõnaraamatus“ (1960) allutatigi vahendit märkiva täiendsõnaga liitsõnad rahvapärasemale genitiivsele liitumisele. Sellise otsuse oli teinud Keele ja Kirjanduse Instituudi teaduslik nõukogu 1952. aasta detsembris (Nurm 1971: 169). Paraku toetuti piiratud ainestikule ja lähtuti eelkõige igapäevakeelest (Erelt jt 1971: 369). Järgmisel kümnendil ilmunud „Eesti keele grammatika III“ liitsõnavihik peab juba sõnades, nagu ving- või vingumürgistus, eeter-või eetrinarkoos, gaas- või gaasikeevitus, masin- või masinalüps, röntgen- või röntgeniravi, aur- või auruküte, siiski selgemaks nominatiivse täiendsõna tarvitamist (Kask 1967: 27). Uuesti tuli liitumise küsimus päevakorda 1970. aastate algul, kui põrkusid järgmise ÕSi koostajate ja Ernst Nurme vaated. 1976. a ÕSi tegijad vastasid Nurme kirjutisele (1971) ühisartikliga (Erelt jt 1971) ning nende ja Nurme seisukohti arutati vabariiklikus õigekeelsuskomisjonis. Nurm pidas võimalikuks rakendada genitiivset liitumist peaaegu terves vahendit märkiva täiendosaga liitsõnade rühmas, tuues peamiseks põhjuseks asjaolu, et seda laadi juhtumeis pole vääriti mõistmine võimalik. ÕSi koostajad rõhutasid objektilise (leiva-, metalli-, pinnalõikamine) ja vahendilise liitumise erinevat tähendussisu (gaas-, hapnik-, kaarlõikamine) ega pidanud veenvaks Nurme katset ajada nominatiivse ja genitiivse liitumise piiri ühelt poolt tegevussisuliste mine- ja us-liitsõnade ja teiselt poolt 
muude tegevust või selle tulemust väljendavate deverbaalse põhisõnaga liitsõnade vahele, nagu traktorkündmine ja traktorikünd, masintõlkimine ja masinatõlge (vt Nurm 1971: 169).

Nurme artiklile oli omakorda eelnenud Rein Kulli kirjutis ÕSi põhimõtetest (1970). Õigekeelsuskomisjoni teine, üsna konservatiivne koosseis kiitis suurema järjekindluse taotlused heaks (komisjoni koosoleku protokoll 31. I 1973), pöörates vahendit märkiva täiendsõnaga liitsõnad üld- ja oskuskeele eri vajadusi toonitavale teele (Erelt 2003: 454). 1976. a ÕSis avaldus see põhimõte varasemast rohkemate rööpvõimaluste esitamises, nt sõnade ahiküte, vähktõbine, laastkatus, sitskleit jts kõrval ka ahjuküte, vähihaige, sitsikleit, laastukatus jts. Termini ja üldkeelesõna vahet rõhutasid erialamärgendid ja ka kõnekeelse ${ }^{2}$ märgend. Ehkki ka Nurm võttis mõneti omaks, et 1960. a ÕSis võidi rahvakeelsuse taotlusega minna liiga kaugele - nominatiivne täiendsõna välistab real juhtudel võimaluse oskussõna sisu valesti mõista, sest genitiivse täiendsõna ja verbaalse põhisõna seost tajutakse harilikult sihitislikuna -, hindas ta 1976. a ÕSi kavandatud liitsõnu masinladu, -lüps, -tõlge, telefon-, telegraafside, ahiküte siiski teiseks äärmuseks. Tähtis on ka see, et Nurm ei pidanud võimalikuks seada oskuskeelele eri reegleid, kuivõrd kirjakeel saavat olla ainult üks.

Pöördeliseks on peetud 1999. a ÕSi, tõlgendades selle liitsõnade vormistust täieliku üleminekuna nominatiivsele liitumisele kirjakeeles ja genitiivse täiendosaga sõnade taandamisena argikeelseks (Vare 2001: 462-472). Tegelikult 1976. aasta normingut ei muudetud. ÕS 1999 üks taotlusi oli üld- ja oskuskeele erinevust selgemini esile tuua. Selleks otstarbeks laiendati märgendi ARGI kasutust, tähistades sellega peale argikeelesõnade järjekindlamalt ka termineile vastavaid üldkeelesõnu. Vormistuse nagu järvkaisel вOт järvekõrkjas ARGI eesmärk oli sõnaraamatu kasutajale näidata, kumb kahest keelendist on termin, mida sobib tarvitada oskuskeeles. Märgend ARGI läks käiku osalt häda sunnil, sest üldkeele märgendit ei ole ega saagi olla (Erelt 2003: 453), teine võimalus olnuks kirjutada pikemad selgitused, nagu on tehtud nt artiklites puit (ehitustermineis puit-, üldkeeles puu-) ja puu (üldkeeles puu-, ehitustermineis puit-). 2013. a ÕSi tarvis otsisid koostajad siiski uue lahenduse, võttes erialamärgendite kõrval senise ARGI-märgendi asemel kasutusele sõnad

${ }^{2}$ Rein Kull (1985: 711) on hiljem pidanud võimalikuks ka üldkeelse märgendit. 
„oskuskeeles“ ja ,üldkeeles“ ning üldkeelesõna juurest termini juurde juhatava kommentaari „oskuskeeles täpsem/täpsemad“. Nt

h`oog: Hoo+vihm (üldkeeles) $=$ hoog+vihm METEO

sits: Sitsi+kardin, sitsi+kleit, sitsi+rätik, oskuskeeles täpsemad sits+kardin, sits+kleit, sits+rätik

Sõnapaare, mille puhul on ÕSis osutatud üld- ja oskuskeele erinevale liitumistavale, on kokku ligi 60 (vt allpool tabelid 1 ja 2). Tähenduse järgi on kaks suuremat rühma need, kus täiendsõna näitab ainet, materjali (siia kuuluvad täiendsõnad kanep, laast, paas, pilbas, roog, siid, sindel, sits, sulg, vatt, vill, õlg) ja vahendit (ahi, elekter, gaas, põrand, tangid). Lisaks on soovitusega varustatud liitsõnu, kus täiendsõna märgib eseme või nähtuse esinemiskuju (hoog-/hoovihm, lill-/lillemuster) või tõstab esile olulise tunnuse (mürk-/mürgiseen). Korpuse andmeist on näha, et vahendit märkiva täiendsõna puhul on uuritud sõnarühmas enamasti ülekaalus genitiivne liitumine. Erandid on tang-/tangisünnitus ning suure sagedusega ahi-/ahjuküte, kus nominatiivne ja genitiivne liitumine on peagu võrdse osakaaluga. Ainet või materjali märkiva täiendsõnaga liitsõnade hulgas on kirev pilt siid-liitsõnade pesas: kleit on pigem nominatiivse, paber, sall, sukad ja tekk pigem genitiivse liitumisega.

Tabel 1. ÕSi kommentaariga soovituspaaride sagedusandmed korpuse põhjal (paksus kirjas on suurem sagedus) ja keelenõuandes

\begin{tabular}{|l|r|l|r|c|}
\hline Nominatiivne & Sagedus & Genitiivne & Sagedus & $\begin{array}{c}\text { Keelenõuandest } \\
\text { küsitud }\end{array}$ \\
\hline ahiküte & $\mathbf{2 5 5 7}$ & ahjuküte & 2291 & 8 \\
\hline elekterkeevitus & 12 & elektrikeevitus & $\mathbf{9 4}$ & 2 \\
\hline elekterküte & 222 & elektriküte & $\mathbf{3 3 6 2}$ & 6 \\
\hline elekterravi & 46 & elektriravi & $\mathbf{4 3 0}$ & 3 \\
\hline gaaskeevitus & 74 & gaasikeevitus & $\mathbf{1 4 2}$ & 1 \\
\hline gaasküte & 145 & gaasiküte & $\mathbf{2 5 0 0}$ & - \\
\hline hoogvihm & 59 & hoovihm & $\mathbf{6 7 8 0}$ & - \\
\hline kanepköis & - & kanepiköis & $\mathbf{4 4}$ & - \\
\hline kanepnöör & - & kanepinöör & $\mathbf{3 7}$ & - \\
\hline kanepriie & - & kanepiriie & $\mathbf{1 7}$ & - \\
\hline laastkatus & 125 & laastukatus & $\mathbf{6 8 7}$ & - \\
\hline laastkorv & 5 & laastukorv & $\mathbf{2 0 9}$ & - \\
\hline
\end{tabular}




\begin{tabular}{|c|c|c|c|c|}
\hline lillmuster & 40 & lillemuster & 895 & 1 \\
\hline mürkseen & 71 & mürgiseen & 241 & 1 \\
\hline nõmm-liivatee & 382 & nõmme-liivatee & 49 & - \\
\hline nõmmnelk & 97 & nõmmenelk & 16 & - \\
\hline paaspõrand & - & paepõrand & 44 & - \\
\hline paassein & - & paesein & 155 & - \\
\hline pilbaskatus & 12 & pilpakatus & 88 & - \\
\hline põrandküte & 205 & põrandaküte & 10473 & 5 \\
\hline roogkatus & 135 & rookatus & 1427 & 1 \\
\hline roogmatt & - & roomatt & 291 & - \\
\hline roogplaat & - & rooplaat & 116 & - \\
\hline siidkleit & 258 & siidikleit & 46 & - \\
\hline siidlint & 64 & siidilint & 46 & - \\
\hline siidniit & 125 & siidiniit & 110 & - \\
\hline siidpaber & 159 & siidipaber & 334 & - \\
\hline siidsall & 298 & siidisall & 426 & - \\
\hline siidsukk & 70 & siidisukk & 142 & - \\
\hline siidtekk & 8 & siiditekk & 40 & - \\
\hline sindelkatus & 186 & sindlikatus & 71 & - \\
\hline sitskardin & 14 & sitsikardin & - & - \\
\hline sitskleit & 59 & sitsikleit & 136 & - \\
\hline sitsrätik & 11 & sitsirätik & 22 & - \\
\hline sulgjopp & 7 & $\begin{array}{l}\text { sulejopp, } \\
\text { sulejope }\end{array}$ & $\begin{array}{r}18, \\
1013\end{array}$ & 2 \\
\hline sulgpadi & 94 & sulepadi & 356 & 1 \\
\hline sulgtekk & 35 & suletekk & 368 & 1 \\
\hline tangsünnitus & 18 & tangisünnitus & 24 & - \\
\hline vattjopp & - & $\begin{array}{l}\text { vatijopp, } \\
\text { vatijope }\end{array}$ & 16,418 & - \\
\hline vattkuub & 10 & vatikuub & 108 & - \\
\hline vattpüks & - & vatipüks & 108 & - \\
\hline vatttekk & - & vatitekk & 575 & - \\
\hline villpadi & - & villapadi & 38 & - \\
\hline õlgkatus & 544 & õlekatus & 23 & - \\
\hline õlgmatt & 44 & õlematt & 10 & - \\
\hline
\end{tabular}

Omaette rühm ÕSi soovituste hulgas on liitsõnad, kus peale täiendosa kuju on erinev ka põhisõna. Peamiselt on need meditsiinisõnad, lisaks mõned taimenimetused (vt tabel 2). Meditsiiniterminite täiendsõna märgib 
vahendit (õhuvann/õhkkümblus) või olulist tunnust (suhkruhaigus/suhkurtõbi, kõrgvererõhuhaigus/kõrgvererõhktõbi, unehaigus/unitõbi, vähihaigus/vähktõbi), taimenimetuste täiendsõna esinemiskohta (järvkaisel/ järvekõrkjas, merihein/mererohi). Korpuse andmeil on nominatiivse ja genitiivse liitumise osatähtsus üsna võrdne sõnades kõrgvererõhktõbi ja kõrgvererõhutõbi, suhkurtõbi ja suhkruhaigus.

Tabel 2. Erineva põhisõnaga soovituspaaride sagedusandmed korpuse põhjal ja keelenõuandes

\begin{tabular}{|l|c|l|r|c|}
\hline Nominatiivne & Sagedus & Genitiivne & Sagedus & $\begin{array}{c}\text { Keele- } \\
\text { nõuandest } \\
\text { küsitud }\end{array}$ \\
\hline järvkaisel & $\mathbf{4 7}$ & järvekõrkjas & 8 & - \\
\hline kõrgvererõhktõbi & 1125 & $\begin{array}{l}\text { kõrgvererõhutõbi* } \\
\text { kõrgvererõhuhaigus }\end{array}$ & $\begin{array}{r}\mathbf{1 2 9 9} \\
40\end{array}$ & 3 \\
\hline kõrgvererõhktõbine & $\mathbf{8}$ & $\begin{array}{l}\text { kõrgvererõhutõbine* } \\
\text { kõrgvererõhuhaige }\end{array}$ & $\begin{array}{r}7 \\
38\end{array}$ & - \\
\hline merihein & 184 & mererohi & $\mathbf{4 3 8}$ & - \\
\hline rindkere & $\mathbf{5 6 4 3}$ & rinnakorv & 1626 & - \\
\hline suhkurtõbi & 2051 & $\begin{array}{l}\text { suhkrutõbi* } \\
\text { suhkruhaigus }\end{array}$ & $\begin{array}{r}530 \\
\mathbf{3 0 4 2}\end{array}$ & 1 \\
\hline suhkurtõbine & 42 & $\begin{array}{l}\text { suhkrutõbine* } \\
\text { suhkruhaige }\end{array}$ & $\begin{array}{r}7 \\
\mathbf{1 6 0 6}\end{array}$ & - \\
\hline unitõbi & $\mathbf{1 1 2}$ & unehaigus & 32 & - \\
\hline unitõbine & - & unehaige & - & - \\
\hline vähktõbine & 6 & vähihaige & $\mathbf{5 8 8 9}$ & - \\
\hline õhkkümblus & - & õhuvann & $\mathbf{3 0 2}$ & - \\
\hline
\end{tabular}

* ÕSist puuduv keelend.

Tabeleist 1 ja 2 on peale korpuseandmete näha ka see, kui sageli on ÕSi soovituspaaride kohta küsitud keelenõuandest. Järgnevas vaadeldakse keelenõuküsimustes ette tulnud liitumisprobleeme võõr- ja omasõnalise täiendsõna ning mõne põhisõnasarja kaupa. 


\section{Võõrsõnalise täiendosaga liitsõnad}

Teatavat liiki võõrsõnade kalduvusele liituda nominatiivselt on viidanud Kask (1967: 30), Tauli (1972: 110), Erelt (2007: 261-278), Liivaku (2008) ja Kasik (2015: 302), põhjalikult on seda käsitlenud Kull (1966). Keelekorralduses ja -nõuandes on järgitud soovitust üldiselt kinni pidada nominatiivse ja genitiivse liitumise reeglitest, ent mingil määral arvestada ka juba toimunud liitumistüübi üldistumist (Erelt 1976: 718).

Keelenõuandest on nominatiivse-genitiivse liitumisega seoses küsitud 368 võõrsõna ja 217 omasõna liitumise kohta. Võõrsõnadena on siin käsitletud nii struktuurilt kui ka päritolult võõraid sõnu, arvestades ühtlasi sõna esinemust võõrsõnade leksikonis. Sõnade sagedus on erinev: on sõnu, mida on keelenõuandest küsitud vaid kord või paar, ja on ka sõnu, mida on küsitud kümneid kordi. Võõrsõnaliste esikomponentide hulgas on kokku 104 sõna, mida on küsitud kolm või enam korda, sagedustabeli tipus on liising (sellega algavate liitsõnade kohta on küsitud 63 korda), grill (58), diisel (55), reklaam (58), kontsert (49), kontroll (40), ekspert (39), treening (38), elekter (35), oliiv (33), aroom (24), eksport (23), remont (23), kultuur (19), vegan (17), röntgen (16), džäss ja transport (mõlemad 14), audiitor, gaas, maakler, pronks ja vanill (13), rokk, struktuur ja transiit (12), kuller ja tekstiil (11), aadress ja projekt (10).

Kas see valik on juhuslik või kutsuvad küsimusi esile kindlat tüüpi võõrsõnad? Vaadeldes esikomponendi vormitüübi mõju võõrsõnade liitumisele, on Kull (1966) toonud esile rühmad, millesse kuuluvatel sõnadel on kalduvus liituda nominatiivselt. Kui võtta need 104 võõrsõna, mida on keelenõuandest küsitud kolm või enam korda, katab Kulli kirjeldatud vormitüübistik neist enamiku:

1) rõhulise lõppsilbiga kahe- või enamasilbilised sõnad, mille lõpus on a) pikk vokaal $+t, d$ (keelenõuandest on küsitud sõnu krediit, $k$ valiteet, mandaat, satelliit, transiit, samuti diftongiga lõppev polaroid), b) pikk vokaal $+l, m, n, r, z ̌ z$ (aerosool, aroom, betoon, drenaaž, hormoon, kromosoom, kultuur, mobiil, montaaž, papilloom, parfüüm, puksiir, reklaam, struktuur, šabloon, tekstiil, vaktsiin, vitamiin, samuti disain, kokteil, maltoos), c) -iiv (akreditiiv, arhiiv, oliiv), d) -ioon (kassatsioon, kollektsioon), e) pikk konsonant (aadress, barokk, fitness, karamell, kontroll, kristall, metall, patrull, vanill), f) konsonantühend (dessert, ekspert, 
eksport, import, klient, kontsert, projekt, remont, renessanss, reserv, transport);

2) album- ja number-tüübi sõnad (audiitor, diisel, doonor, elekter, filter, kaabel, kalender, konteiner, kuller, kuraator, maakler, manööver, mentor, pahtel, palsam, röntgen, sponsor, tempel);

3) ühesilbilised võõrpäritolu sõnad (bluus, džäss, fänn, gaas, geel, geen, grill, jaht, mass, plast, pronks, rokk, räpp, seks, skaut, sport, stress, test, veeb, vipp, vokk);

4) teisevältelised sõnad (doping, faktooring, kliiring, liising, treening).

Lisaks on enim küsitud võõrsõnaliste esikomponentide hulgas veel akvaarium-tüübist alumiinium, petrooleum, juunior, seenior, seminartüübist alkohol, insener, mahagon ja õpik-tüübi sõna vegan.

\subsection{Teisevältelised ing-lõpulised sõnad}

Teisevältelistest ing-lõpulistest sõnadest on keelenõust peale liisingu küsitud ka vanemate laenude treening ja doping ning majandusterminite kliiring ja faktooring liitumise kohta. Kui dopingu, faktooringu ja kliiringu puhul on tegemist üksikute liitsõnadega, siis nii liisingu kui ka treeningu puhul on aegade jooksul läbi küsitud terve hulk liitsõnu. Liising-alguliste liitsõnade korduvad küsimused on olnud seotud põhisõnadega leping (13 korda), firma (12), tehing (8), taotlus (5). Nominatiivset liitumist on keelenõuandjad soovitanud sõnades liisinglaen, -ost, -teenus, -tehing, genitiivset sõnades nagu liisinguauto, -ettevõte, -ettevõtja, -firma, -intress, -leping, -makse, -pakkumine, -periood, -sõiduk, -taotlus, -teenus, -tähtaeg.

ÕS esitab liising-algulised liitsõnad valdavalt genitiivse täiendosaga: liisinguandja, -võtja, -taotlus (objektitähendusega sõnad), -firma, -leping, -tähtaeg, -vara (nagu reisifirma, laenuleping, müügileping, laenutähtaeg). Korpuseuuring näitab, et objektitähenduse puhul on ka kasutuses valdav just genitiivne liitumine (liisinguandja, -pakkuja, -pakkumine, -taotlus, -võtja). Kuuluvust või otstarvet näitavaid sõnu liidetakse pigem omastavaliselt (liisinguarve, -ese, -intress, -jääk, -kalkulaator, -klient, -kohustus, -objekt, -summa, -sõiduk, -tingimus, -turg, -võimalus, -võlg), osa suurema sagedusega sõnu siiski nii nimetavaliselt kui ka omastavaliselt (liising $(u)$ auto, liising(u)ettevõte, liising(u)firma, liising(u)leping, liising $(u)$ makse, liising(u)periood, liising $(u)$ portfell $)$. Ainus nominatiivse täiendosaga 
liitsõna ÕSis on liisingtehing. Normingu lähtekohaks on põhimõte, et liitsõna täiendosa, mis märgib seda, kes või mis põhiosaga nimetatu on (tehing on liising), sobib liita nimetavaliselt. Kasutusuuring näitab seda tüüpi sõnades ootuspärase nimetavalise liitumise kõrval (liisingfinantseerimine) siiski ka omastavalist (liisingtehing 59 ja liisingutehing 79 - nagu kauba-, laenu-, müügitehing).

Liising-alguliste liitsõnade puhul tervikuna on kasutuses ilmne omastavalise liitumise domineerimine. Korpusest tuli esile 48 liitsõna, mille esinemissagedus oli 40 või üle selle, neist 36 olid omastavalise ja 12 nimetavalise täiendsõnaga. Kümne kõige sagedasema liitsõna hulgas oli kaheksa omastavalise ja kaks nimetavalise täiendosaga: liisingufirma 2207, liisinguleping 1863, liisinguandja 1626, liisinguvõtja 1449, liisingfirma 977, liisingumakse 940 (võrdluseks: liisingmakse 212), liisinguperiood 725 (liisingperiood 173), liisingleping 546, liisinguese 522, liisinguauto 510 (liisingauto 186). 1990. aastatel käibele tulnud liising-liitsõnade varieeruva vormi taga võib ühelt poolt näha samakujuliste inglise sõnaühendite eeskuju, mis toetab nominatiivset liitumist (liisingfirma nagu leasing company), teisalt võib oma mõju olla keelesoovitustel (vt nt Raadik 2005: 58-62). Ka omasõnade eeskujust lähtuv genitiivliitumine (liisinguleping nagu laenu-, müügileping) on tõenäoliselt tugevnenud sedamööda, kuidas liising kui nähtus on meil tuntumaks saanud.

Erinevalt liising-liitsõnadest on treening-liitsõnade hulgas korduvaid küsimusi vähe. Genitiivse liitumisega on küsijaile soovitatud sõnu treeningugraafi, -grupp, -innukus, -jalats, -keskus, -klubi, -koormus, -kord, -maht, -moon, -nõustamine, -plaan, -päev, -päevik, -relv, -režiim, -rühm, -saal, -stiil, -süsteem, -tasu, -tingimus, -vahend, nii nominatiivse kui ka genitiivse liitumisega sõnu treening $(u)$ dress, treening $(u) p u d e l$, treening $(u)$ püksid, treening $(u)$ riided, treening $(u)$ rätik. Küsitud sõnade hulgas on nii neid, mis sõnastikes olemas, kui ka neid, mis pole sinna jõudnud. Kordagi ei ole aga keelenõust küsitud selliste sõnade kohta, kus senine norming näeb ette üksnes nominatiivse liitumise.

Samadel põhjustel nagu liising-liitsõnad, st inglise sõnaühendite mõju kombineerituna omasõnade eeskujust lähtuva genitiivse liitumise ja keelesoovitustega, on treening-täiendsõnaga liitsõnad tervikuna kirev rühm. ÕSis on treening-liitsõnu esitatud kolmel moel. Nominatiivse liitumisega on treeninglend, -mať̌, -mäng, -sõit, -võistlus, genitiivse liitumisega treeningukava,-koormus, -meetod, -partner, -plaan, -päevik, 
-rühm, -seade, nii nominatiivse kui ka genitiivsega treening $(u)$ dress, treening $(u)$ laager, treening $(u)$ pluus, treening $(u)$ püksid, treening $(u)$ tund, treening $(u) \ddot{u} l i k o n d$. Korpuse andmeil lähevad norming ja tegelik kasutus kokku ÕSi nominatiivse liitumise rühmas, täpsemini neis sõnades, kus täiendsõna näitab, kes või mis on põhisõnaga väljendatu (treeningmäng, treeningsõit - mäng, sõit on ühtlasi treening). Meenutame, et nende sõnade kohta ei ole ka keelenõust küsitud. Rühmas, mis on ÕSis fikseeritud üksnes genitiivse liitumisega, näeb tegelikus tarvituses mõlemat liitumisviisi, kuid seejuures on kõigi sõnade puhul ülekaalus just nominatiivne liitumine. Selles rühmas tasuks edaspidi kaaluda mõlema liitumisviisi esitamist, nt treening $(u)$ kava, treening $(u)$ koormus, treening $(u)$ partner, treening $(u)$ plaan, treening $(u)$ päevik, treening $(u)$ rühm, treening $(u)$ seade. Rühmas, kus ÕSis on antud mõlemad liitumisviisid, eristub korpuse andmeil omakorda kaks väiksemat rühma. Rõivaesemeid tähistavaid sõnu on tegelikus tarvituses liidetud peamiselt nominatiivselt, kuid nende sõnade sagedus on korpuses üldse väga väike. Suurema sagedusega on liitsõnad treening-/ treeningulaager ja treening-/treeningutund, nende puhul on täiendsõna liidetud sagedamini nominatiivselt, harvemini genitiivselt. See langeb ka kokku ÕSi norminguga, mis möönab mõlema liitumisviisi võimalikkust.

1960. a ÕSis olid treening-liitsõnad antud peamiselt genitiivse täiendosaga, erandiks olid treeningdress ning treeningmatš, -mäng, -sõit ja -võistlus. 1976. a ÕSi eel juhtis Kull tähelepanu, et treeningriietusesemeid tähistavad sõnad on tegelikus kasutuses nominatiivse täiendsõnaga, ning imestas, miks ei ole ÕSis treeningdressi kõrval peetud võimalikuks treeningpükse ega treeningülikonda (Kull 1966: 291). 1976. a ÕSis oli kõigil kolmel juba antud nii nominatiivne kui ka genitiivne liitumine, kuid korpuseuuring kinnitab Kulli väidet: need sõnad, kuigi korpuses üldiselt väikese sagedusega, kalduvad olema nominatiivse täiendosaga. Sellised on ÕSi liitsõnavalikust nt treeningdress, -pluus, -püksid, -ülikond, keelenõuande küsimuste hulgast aga nt treeningjalats, -riided, -rätik. Samasse rühma kalduvad ka muud keelenõust küsitud treeninguvahendid, nt treeningmoon, -relv, -pudel. Peale rõivaesemete esitas 1976. a ÕS nii nominatiivse kui ka genitiivse täiendosaga ka tunni (treeningtund ja treeningutund), 1999. a ÕS lisas aga laagri (treeninglaager ja treeningulaager), nagu oli ette pannud Kull (1966: 291).

Kui vaadata korpusest 30 kõige suurema sagedusega treening-liitsõna, on nende hulgas vaid 4 genitiivse täiendsõnaga: 8 . kohal treeningulaager 
(vrd 1. kohal nominatiivne treeninglaager), 19. treeningukaaslane (26. treeningkaaslane), 27. treeninguplaan (3. treeningplaan), 29. treeningukoormus (10. treeningkoormus). Liising-liitsõnadega võrreldes on treening-liitsõnad seega palju enam nominatiivse liitumise poole kaldunud.

\subsection{Esmavältelised võõrsõnad: vegan}

Esmavältelistest võõrsõnadest on küsijaile ja ka vastajaile enim peavalu teinud inglise laen vegan, mis hakkas levima 2000. aastatel. Inglise vegan on tekkinud sõna vegetarian 'taimetoitlane; taimne, taimetoidu-' kokkutõmbe teel ning nagu aluskeelendil nii on ka vegan'il inglise keeles kaks tähendust: 'täistaimetoitlane' ja 'täiesti taimne, täistaimetoidu-'.

ÕSi jõudis vegan esimest korda 2013. aastal, esimesed liitsõnad, genitiivse täiendosaga veganikohvik ja veganitoit, esitas 2018. a ÕS. Keelenõuandmebaasi esimene vegani-teemaline kanne (veganitoit) pärineb 2012. aastast, 2014 selgitas Tuuli Rehemaa keelenõuande veebilehel, et nimisõnaga vegan algavates liitsõnades sobiks eelistada genitiivset täiendsõna (veganiküpsised, veganitoit, veganielustiil, veganikohvik jt). Veganid ise on käsitanud eesti vegan-sõna nii nimi- kui ka käändumatu omadussõnana. Viimase väitega on muu hulgas soovitud põhjendada ühildamata lahkukirjutust nimetustes nagu Eesti Vegan Selts, Vegan Restoran V, Miku Vegan Kohvik. 2014. aasta sügisel peetud ühisarutelul paraku kokkuleppele ei jõutud, sest veganitele oli vastumeelne omastava käände soovitus (veganitoit, veganite selts), keelekorraldajaile omakorda inglise väljendeid kopeeriv lahkukirjutus (vegan toit nagu ,vegan food“või vegan restoran nagu ,vegan restaurant"). Veganite vastuargument omastavale käändele oli selle seos kuuluvusega, kuivõrd ,vegan restorani“" omanikud ega külastajad või ,,vegan seltsi“ liikmed ei pruugi olla ise veganid, „,vegan toit" ei pea aga tingimata olema veganite jaoks või veganite valmistatud. ${ }^{3}$ Keelekorraldajad kahtlesid, kas pidada veganit käändumatuks omadussõnaks (vegan toidud nagu akuraat mehed ${ }^{4}$ ), ja tõmbasid mõttes paralleele koššer-sõnaga. Kompromiss olnuks nominatiivse täiendsõna möönmine,

3 Eesti Vegan Seltsi e-kiri 21. IX 2014.

4 Kalduvusele võõrkeelseid adjektiive ühildamata jätta on mh osutanud Aavik (1914: 37), tuues näiteid nagu prostoi inimesed, undrehti asjad, akuraat tööd, modern mööblid, intelligent inimesed. 
kuid keelekorraldajad polnud 2014. aastal selleks veel valmis, lootes, et liitsõnad suudetakse allutada eesti mallidele.

Keelenõuande korduv küsimus ja vastus on olnud veganitoit (5), lisaks on küsijaile soovitatud genitiivse täiendsõnaga liitsõnu veganijaanituli, -jalats, -kook, -liköör, -margariin, -pasta, -roog, -šokolaad, -toode, nominatiivse täiendosaga vegankruiisija, vegantoidukoht, veganökoketšup (kaks viimast, 2019. aasta vastust kajastavad keelekorraldajate seisukohtade teisenemist). Korpuseuuring näitab, et vegan-sõnu liidetakse peamiselt nominatiivselt, nt vegan-/veganitoit 525/111 (lisaks sidekriipsuga vegan-toit 60), vegan-/veganitoode 187/22 (vegan-toode 23), vegan-/ veganidieet $83 / 0$ (vegan-dieet 20 ), vegan-/veganirestoran $71 / 9$, vegan-/ veganimenü̈ 64/5, vegan-/veganikohvik 53/5, vegan-/veganiburger 46/5. Kindel nominatiivse liitumise piirkond on liitsõnad, kus täiendosa märgib seda, kes või mis on põhisõnaga väljendatu (veganlaps, veganpere, vegankokk, vegankruiisija, veganvanem), ülejäänutes võiks normimisel möönda nominatiivse täiendosa ülekaalu, säilitades seekõrval siiski ka eesti liitsõnade eeskujust lähtuva genitiivi võimaluse (veganitoit nagu kooli-, paki-, imiku-, vaimutoit või veganikohvik nagu tänava-, katuse-, sõoriku-, lastekohvik). Kuivõrd genitiivi võimalus ka kasutuses realiseerub, näitab tulevik.

\section{3. Ühesilbilised võõrpäritolu sõnad}

Ühesilbilistest võõrpäritolu sõnadest on küsijaid kõige enam huvitanud grill-liitsõnad, muusikastiilide nimetused ja materjalisõnad (plast, pronks). Sõna pronks puhul on õigupoolest küsitud vaid kaht liitsõna: pronksiöö (korpuses nom 3714, gen 858) ja pronksivärv. Üks pronksiöö küsija on lausa ahastanud: sada korda olen küsinud, ikka meeles ei seisa.

Muusikastiilide bluus, džäss, rokk ja räpp puhul on küsijaile enim kõhklusi valmistanud täiendosa liitmine isikut tähistavatele põhisõnadele, nagu laulja (küsijaile on soovitatud liitsõnu bluusi-, džäss- ja džässi-, rokilaulja), kitarrist (bluusi-, džässkitarrist), muusik (džässi-, rokkmuusik), pianist (džässipianist), staar (roki- ja rokkstaar), lisaks on küsitud põhisõnade festival (džässifestival), kontsert (džässi-, rokk-, räpikontsert), lugu (rokilugu), muusika (džäss-, rokk-, räppmuusika), stiil (räpistiil) jt kohta. Nagu ikka, põhjustab selleski rühmas variantsust inglise keelest pärit terviklaenude ja omasõnade võistlev mõju. 
ÕSis on räpp-algulistest liitsõnadest nominatiivse täiendsõnaga peale räppmuиsiku ka räpplugu ja räppvideo, korpuse andmeil on kasutuses eelistatud genitiivse liitumisega kujusid räpilugu ja räpivideo. ÕSist puudub üsna suure sagedusega ja korpuse andmeil kindlalt nominatiivse täiendosaga liitsõna räppmuusika. Rokk-liitsõnade puhul vastab ÕSi norming üldiselt korpuse andmetele, omastavalise täiendsõnaga on rokiklassika, rokiklubi, rokilegend, nimetavalisega rokkansambel, rokkooper, rokkmuusika. Pigem kaheti liituvad ÕSis genitiivselt antud rokifestival, rokikontsert, rokitäht ja nominatiivselt antud rokklaulja.

Džäss-liitsõnade puhul fikseeris ÕS 1976 nominatiivse täiendsõnaga $d \check{z a ̈ s s m u u s i k a, ~ a g a ~ g e n i t i i v s e ~ t a ̈ i e n d s o ̃ n a g a ~ d z ̌ a ̈ s s i m u u s i k u ~ j a ~ d z ̌ a ̈ s s i l a u l j a, ~}$ sama norming kandus edasi ka järgmistesse ÕSidesse. 2007. aastal juhtis Kalju Terasmaa ÕSi koostajate tähelepanu muusikute tavale kasutada sõnades nagu džässorkester, -koor, -ansambel, -muusik, -laulja, -pianist nimetavalist liitumist. ${ }^{5}$ ÕSi koostajad möönsid dž̈ssmuusiku ja -laulja reeglite alla paindumatust, kui kõrval on tugevad analoogid rokk-, räpp-, folk-sõnadega (Tiiu Erelti vastus), ning 2013. a ÕSis on fikseeritud juba nominatiivse liitumisega džässlaulja, džässmuusik. Senine genitiivne norming on tõenäoliselt siiski oma jälje jätnud, sest korpuses on mõlema sõna puhul nominatiivse täiendsõna kõrval näha ka genitiivset ( $d z \check{z} a s s-/$ džässilaulja 139/106, džäss-/džässimuusik 640/67).

Grill-algulisi liitsõnu saab õigupoolest jagada kaheks: ühtedel on täiendsõnaks nimisõna grill 'grillimisriist', teistel tegusõna grillima tüvi grill- tähenduses 'grillimis-' või 'grillitud'. ÕSi artiklis grill on antud genitiivse täiendosaga liitsõnad grillipidu, grillihooaeg ja grillitarvik (grilliga seotud asjad või nähtused), artiklis grill- aga liitsõnad grillahi, grillrest, grillsüsi, grillbaar (grillimisahi, -rest jne); grillkaste, grillmaitseaine (grillimiskaste, -maitseaine); grillkana, grillliha, grillvorst (grillimiseks mõeldud või grillitud kana, liha, vorst). Piirid on paraku hajusad, näiteks on ÕSis fikseeritud grillitarvik 'grilli juurde kuuluv tarvik' ja grillrest 'grillimisrest', kuid mõeldes grillimiseks vajalikku tarvikut või grilli juurde kuuluvat resti, on täiesti võimalik öelda ka grilltarvik ja grillirest. Pilguheit korpusesse kinnitab siiski ÕSi fikseeringuid: sõnadele pidu, hooaeg, tarvik liidetakse täiendsõna pigem genitiivselt (grill-/grillipidu 204/852, grill-/ grillihooaeg 79/531, grill-/grillitarvik 49/79), sõnad ahi, rest, süsi, baar, kaste, kana, liha, vorst jts on aga ülekaalukalt grill-esiosaga.

${ }_{5}^{5}$ Kalju Terasmaa e-kiri 10. IX 2007. 
Korduvaid küsimusi grill-/grillipeo kõrval on olnud grill-/grillimeister, vastajad on mõlemat sõnakuju võimalikuks pidanud (korpuses grillmeister 414, grillimeister 223). Grill-liitsõnad on ka üks neid rühmi, kus nõuandjad on oma vastustes eriti sageli otsinud tuge analoogiast, nt grillrest (nagu grillpann), grillrestoran (nagu grillbaar), grillvarras (nagu grillrest), grillõli (nagu grillsüsi), grilliaed (nagu grillipidu), grillitangid (nagu grillitarvikud), grillivein (nagu grillipidu, grillihooaeg).

\subsection{Album- ja number-tüübi võõrsõnad}

Album-tüüpi sõnade rühmas on mh küsimusi põhjustanud isikuid tähistavad nimetused, nagu audiitor, kuller, maakler, mentor, proviisor, sponsor. Kuidas liita, kui põhisõna tähistab näiteks ettevõtet, firmat, teenust, lepingut? ÕS pakub vähest tuge, esitades nominatiivse täiendosaga liitsõnad audiitorkontroll, kullerpost, sponsorettevõte, genitiivsega maaklerifirma, -leping, -tasu, sponsoriraha. Keelenõuande vastustes domineerivad genitiivse täiendosaga liitsõnad, nagu audiitoribüroo, -firma, -kogu, -teenus, -tegevus, -tunnistus, kullerifirma, -teenus, -tellimus, maaklerifirma, -leping, -teenus, -tegevus, mentoriklubi, -programm, -teenus, sponsorileping, -pakett, -programm, -tunnistus; nominatiivse täiendosaga on nt audiitorbüroo (sama sõna on soovitatud ka genitiivsena) ja audiitorettevõte. Kui omasõnad liituvad põhisõnadele ettevõte, firma, leping, teenus, tegevus jts mitmesuguses tähenduses enamasti genitiivselt (riigi-, lennuettevõte, reisi-, uuringufirma, laenu-, mü̈̈gileping, panga-, veoteenus, sõja-, õppetegevus), siis album-tüüpi võõresikomponendid enamasti nominatiivselt: audiitorbüroo tuli korpuses ette 418 ja audiitoribüroo 22 korda, audiitor-/ audiitoriettevõte 108/0, audiitor-/audiitorifirma 1768/45, kuller-/kullerifirma 1114/159, sponsor-/sponsorifirma 283/0, mentor-/mentoriklubi 690/0, kuller-/kulleriteenus 2151/282, audiitor-/audiitoriteenus 477/17, audiitor-/audiitoritegevus 1218/12, maakler-/maakleritegevus 282/39, sponsor-/sponsorileping 1368/54, sponsor-/sponsoriraha 745/59, mentor-/ mentoriprogramm 834/41. Täiendsõna võib siin mh osutada ka sellele, kes või mis on põhisõnaga märgitu (nt audiitor-, kuller-, sponsorfirma 'firma on audiitor, kuller, sponsor'), selle sisuga liitsõnad on aga üks kindlamaid nominatiivse liitumise piirkondi. Genitiivse liitumise suuremat osatähtsust või isegi ülekaalu näeb mõne maakler- ja proviisor-algulise liitsõna puhul, nagu maakler-/maaklerifirma 690/370, proviisor-/proviisoriapteek 
214/114, maakler-/maaklerileping 188/282, maakler-/maakleriteenus 568/761. Küsimuste hulga järgi otsustades on album-võõrsõnade rühma kaks kõige raskemat liitsõna kuller(i)teenus ja maakler(i)teenus, mis ka tegelikus kasutuses esinevad variantsena.

Number-tüübis on enim küsitud diisel- (sh diislikütus 30 küsimust, diiselmootor 11) ja elekter-algulisi liitsõnu. Diisel-liitsõnade puhul kajastab ÕS tegeliku kasutuse tendentse võrdlemisi täpselt: nominatiivsed diiselmootor (nom 13 340, gen 54), diiselauto (1475/25), diiselrong (1619/0), diiselvedur (211/0) jts, genitiivsed diislikütus (2007 / 11 008), diisliõli (40/95).

ÕSi norming on muutunud mõne pahtel-ja trühvel-algulise sõna puhul. Kuivõrd pahtli tähendus on varem olnud 'labidake pragude kittimiseks' (vt EÕS II kd 1930, ÕS 1976 lisas sellele pahtelkiti tähenduse), fikseerisid ÕSid liitsõna pahtellabidas (labidas on pahtel) nominatiivse täiendosaga. Alates 2006. a ÕSist on nominatiivse pahtellabida kõrval esitatud ka genitiivne pahtlilabidas. Domineerib siiski genitiivne liitumine: 844 pahtlilabida kõrval tuli korpusest välja vaid 24 pahtellabidat, seda tasub edaspidi normingus arvestada.

Trühvel-algulistest liitsõnadest oli ÕSides pikka aega vaid nominatiivse liitumisega trühveltort, ajapikku on keelde lisandunud uusi liitsõnu, ühtlasi on nad hakanud alluma toidusõnade rühmas üsna tavapärasele genitiivsele liitumisele: trühvlitort (nagu vahvlitort, marjakook), trühvlikomm (nagu koore-, pulgakomm), trühvlikaste (nagu seene-, salatikaste). ÕS 2018 on seda tendentsi arvestades lisanud nominatiivse täiendosaga liitsõnale trühveltort genitiivse täiendosaga trühvlitordi, samuti esitanud liitsõnad trühvlikomm, trühvliomlett. Trühvlikommi sõnas ei näi täiendosa käänet olevat mõjutanud ka see, et täiendsõna tähendus (komm on trühvel) eeldaks pigem nominatiivset liitumist.

\subsection{Rõhulise lõppsilbiga võõrsõnad}

Rõhulise lõppsilbiga kahe- ja enamasilbilistest sõnadest on enim küsimusi põhjustanud reklaam, oliiv, aroom, kultuur, struktuur, transiit, tekstiil (rõhulises lõppsilbis on pikk vokaal), kontsert, kontroll, ekspert, eksport, remont, transport, vanill, aadress, projekt (rõhulises lõppsilbis on pikk konsonant või konsonantühend). Siin on suuri rühmi, kus on vaid üksikuid korduvaid küsimusi (nt eksport-, reklaam-, kontroll-, kultuur-liitsõnad), 
ja ka rühmi, kus hulga küsimusi on andnud üks-kaks sõna (oliiv-, vanillliitsõnad). Oliivi puhul on küsitud, kuidas liita seda põhisõnale õli, norming on olnud genitiivne (oliiviõli nagu toidu-, taime-, rapsiõli). Korpuses näeb ülekaaluka genitiivi kõrval (14 096 tulemust) päris palju ka nominatiivset liitumist (3324). Vanill-rühma korduv küsimus on vanill-/vanillisuhkur, mis oli kuni 2006. a ÕSini fikseeritud nominatiivse täiendosaga ning alates 2013. a ÕSist kaheti, s.o vanill(i)suhkur. Normingu muutust toetab kasutus (nom 885, gen 1634). Tegelikule keeletarvitusele tuginedes on 2013. a ÕSis sätitud muidki toidusõnu, nt on nominatiivse täiendsõnaga liitsõnale karamellkissell lisatud toidusõnadele omase genitiivse täiendsõnaga karamellikissell (Mäearu 2015: 133). Remont-liitsõnade korduv küsimus on ülekaalukalt remont-/remonditöö, mis on alates 1960. a ÕSist olnud kaheti normitud (remonttöö = remonditöö), korpuses vastavalt 4042 ja 7230 tulemust. Nagu näha, ei pruugi kasutusest lähtuvate rööpvormide andmine alati kõhklusi vähendada.

1960. ja 1976. a ÕS fikseerisid nominatiivse liitumisega arheoloogiatermini kultuurkiht. ÕS 1999 lisas oskuskeele sisule üldkeeles levinud piltliku tähenduse ning asendas nominatiivse täiendsõna genitiivsega. Reeglipärane genitiiv - kultuurikiht kui mõne tegevuse (kultuuri) tagajärjel või kaasmõjul tekkinud kiht, mitte 'kultuurne' ega 'kultuuristatud' kiht $^{6}$ - on olnud arheoloogidele siiski vastuvõetamatu. Kahes kultuurliitsõnas lisas ÕS 1999 senisele nominatiivsele liitumisele genitiivse: kultuurautonoomia ja kultuurkapitali kõrvale tulid kultuuriautonoomia ja kultuurikapital. Sama võiks kaaluda ka kultuur-/kultuurikihi puhul, korpuse andmedki näitavad siin nominatiivsel ja genitiivsel liitumisel üsna võrdset sagedust.

Suured rühmad on abstraktsema tähendusega kontroll- ja projektalgulised liitsõnad, kus nii küsijail kui ka vastajail on olnud raskusi tähendusele vastava vormi leidmisel. ÕSide liitsõnavalikus on ülekaalus olnud nominatiivse täiendosaga kontroll-sõnad, nt 1976. a ÕSis on kokku ligi kuuskümmend kontroll-algulist liitsõna, nende hulgas ainult kaks on genitiivse täiendsõnaga (kontrollialune ja kontrolliaruanne). Keelenõuküsijaile on soovitatud nominatiivse täiendsõnaga liitsõnu kontrollgrupp, -menetlus, -organ, -tegevus, -toiming, genitiivsega kontrolliakt, -aruanne, -asutus, -graafik, -komisjon, -meede, -meetod, -mehhanism, -objekt, -osakond, -periood, -poliitika, -ruum, -süsteem, -ülesanne, kaheti kontroll-/

${ }^{6}$ Tiiu Erelti kiri Helju Valsile 20. VIII 2008. 
kontrollisüsteem. Neist sõnadest ainult kolm sisalduvad ka ÕSis (genitiivne kontrolliaruanne, nominatiivsed kontrollkomisjon, -süsteem).

Korpuses näeb enamiku küsitud sõnade puhul nii nominatiivset kui ka genitiivset liitumist. Suurema sagedusega sõnadest on pigem nominatiivse liitumisega kontrollakt (nom 947, gen 72), kontrollgrupp (1324/18), kontrollkomisjon (427/121), kontrollorgan (2359/205), kontrollruum $(145 / 20)$, pigem genitiivselt näivad liituvat kontrolliaruanne (104/425), kontrolliasutus (234/849), kontrollimeede (255/627), kontrollimeetod (69/229), kontrollimehhanism (774/1357), kontrollimenetlus (84/511), kontrolliosakond (28/739), kontrollitegevus (108/315), kontrollitulemus (38/145), kontrolliülesanne (84/116). Enam-vähem võrdselt on nominatiivi ja genitiivi sõnades kontroll-/kontrolliperiood (82/99), kontroll-/kontrollisüsteem (1657/1867) ja kontroll-/kontrollitoiming (148/185). Täiendsõna käänet võivad siin sõna vormitüübist ja tähendusest tugevamini mõjutada hoopis eeskujusõnad: kontrollakt liitub nagu haldus-, normatiivakt, lähedase sisuga kontrolliaruanne seevastu nagu kasumi- või kvartaliaruanne; kontrollkomisjon ja kontrollorgan liituvad nagu majandus-, mandaatkomisjon või lepitusorgan; kontrolliasutus ja kontrolliosakond nagu riigi-, ametiasutus, müügiosakond. Kui kontroll-sõnal on omakorda täiend, domineerib genitiivne liitumine, nt järel-, esmakontrolliakt, piiri-, tervisekontrolliasutus, relvastus-, laevakontrolligrupp, eelarvekontrollikomisjon, sise-, riigikontrolliorgan, sise-, tolli-, transpordi-, finantskontrolliosakond, sise-, enese-, kvaliteedikontrollisüsteem.

Projekt-liitsõnade esitus ÕSis vastab põhijoontes korpuse andmetele: nominatiivselt liituvad projektdokumentatsioon, -võimsus, -õpe, genitiivselt projektibüroo, -insener, -juht, -kirjutaja. Küsijaid on huvitanud projekti põhjal tegutsevate kollektiivide nimetused, vastajad on soovitanud selles rühmas üsna ühtlaselt genitiivset liitumist. Korpuse andmeil kalduvad genitiivselt liituma suurema sagedusega projektirühm (37/161) ja projektiteater (8/400), varieeruvama vormiga on väiksema sagedusega liitsõnad projekt-/projektigrupp (99/142), projekt-/projektikoor (85/90), projekt-/projektiorganisatsioon (87/28), projekt-/projektiorkester (47/24).

Niisama visa vastupanu kui esmavälteline vegan on keelekorraldajate soovitustele osutanud ka kolmandavälteline ekspert. ÕSi liitsõnanäited on olnud genitiivse täiendsõnaga (alates 1999. a ÕSist eksperdiarvamus, eksperdihinnang, 2006 lisandus eksperdirühm), kõiki kolme on 
ka keelenõuandest korduvalt küsitud. Keelenõuvastustes domineerib genitiivne liitumine (eksperdiabi, -arvamus, -firma, -grupp, -hinnang, -hooldus, -intervjuu, -komisjon, -komitee, -nõukogu, -rühm, -tasu, -teadmised, -teenus, -uuring), kõikuv on olnud soovitus sõnade ekspert-/ eksperdikomisjon ja ekspert-leksperdinõukogu puhul (komisjon, nõukogu on ekspert). Korpus näitab sagedasemates ekspert-liitsõnades nominatiivse liitumise ülekaalu: ekspert-leksperdihinnang 6015/994, ekspert-/ eksperdigrupp 3819/103, ekspert-/eksperdikomisjon 3511/437, ekspert-/ eksperdiarvamus 2006/972, ekspert-/eksperdirühm 1166/594. Kõrvuti projekti, kulleri jt sellistega on ekspert ka üks neid vanemaid võõrsõnu, millega just eriti viimastel aastakümnetel on hakatud moodustama rohkesti uusi liitsõnu, nt Digari eesti artiklite portaalis on mõni üksik ekspert-/ eksperdiarvamus, ekspert-/eksperdigrupp, ekspert-leksperdihinnang 1970.-1980ndatel ja kuller-/kullerifirma, kuller-/kulleriteenus 1990ndatel, kuid sagedus kasvab märkimisväärselt 2000.-2010. aastatel.

\section{Omasõnalise täiendosaga liitsõnad}

Omasõnade hulgas on 58 sellist, mille liitumise kohta on keelenõuandest küsitud kolm või enam korda. Sagedustabeli tipus on mets (mets-liitsõnade kohta on küsitud 29 korda), lópp (26), taust (25), vesi (22), isik (21), ravim (18), amet (17), sidrun (15), puit (14), suvi (13), meri, paber ja sade (12), röst (11), lõhn (10), pidu ja sukk (9), ahi, nokk ja tekst (8), lahing, laps, lumi, masin, põrand ja taim (7). On kaheldud vanades tuttavates liitsõnades, nagu asitõend, jalgrada, kurjategija, marjapuu (Riikoja 1962: 616 andmeil esineb läänemurdes ja saartel ka nominatiivse täiendsõnaga maripuu), mille norming langeb kokku kasutusega, või laudlina, lustmäng, tükksuhkur, surmavaikus, tagumikutund, vigurivänt, mis esinevad ka korpuses variantsena (nt laudlina 2872 ja laualina 442, tükksuhkur 99 ja tükisuhkur 69, vigurvänt 298 ja vigurivänt 405). On soovitud tuge uute oskussõnade vormistamiseks, nt nominatiivsed küünarkark, nimisponsor, omanikfirma, pistikhübriid (korpuses pistik- 951, pistiku-331), tänavmuuseum, genitiivsed hinnaelastsus, näpuraamat, parveõppus, pilveteenus, pulganukk, sädemetester. Nagu võõrsõnade rühmas, nii on omasõnadegi hulgas liitsõnu, mida on korduvalt küsitud, nt ahi-/ahjuküte, nokk-/nokamüts, sukk-/sukapüksid (nende kolme täiendsõna puhul ongi küsitud vaid üht liitsõna), isik-/isikunäitus, röst-/röstisai, sade-/sademevesi, sidrun-/ 
sidrunihape, suvi-/suvekõrvits, tekst-/tekstisõnum. Kaks kolmandikku mets-liitsõnade küsimustest käivad metspähkli kohta.

ÕSi fikseeringud vastavad siin korpuse andmetele: pigem genitiivselt liituvad isikunäitus (nagu rühmanäitus), sademevesi (nagu vihmavesi) ja pigem nominatiivselt röstsai (mida võib käsitada ka verbitüvena, vrd eespool grill-liitsõnad), sidrunhape (nagu piim-, rasv-, soolhape, nominatiivselt on fikseeritud kogu hapete ja hapendite sari), suvikõrvits (nagu suviraps, suvispinat). Genitiivselt kaldub siiski liituma tekst-/tekstisõnum, ehkki kõrval on samas sõnumite sarjas kindlalt nominatiivsed pilt- ja häälsõnum (sõnum on hääl, pilt või tekst). Nokkmüts, tuttmüts ja sukkpüksid on ÕSis fikseeritud nominatiivse liitumisega, lähtudes põhimõttest, et olulist tunnust või esinemiskuju esiletõstev täiendsõna liidetakse nominatiivselt. ÕS 2018 lisas sellesse ritta kontskinga, sidudes nominatiivse liitumise eeskätt oskuskeelega (jätkates lakk-, nael-, pannal-, platvorm-, rihm- ja varvaskinga sarja), ning möönis üldkeeles ka genitiivse täiendosaga liitsõna kontsaking võimalikkust. Korpuse andmeil on kontskinga, nokkmütsi ja ka tuttmütsi puhul genitiivne liitumine ülekaalus, sukkpükste puhul domineerib nominatiivne liitumine.

Omastava käände põhifunktsioone on osutada, et liitsõna täiendsõna väljendab kuuluvust. See on tekitanud keelenõuküsijais kartuse, et mitmuse omastavas täiendosaga liitsõnu lasteporno(graafia) ja lasteprostitutsioon võiks tõlgendada kui lastele mõeldud pornograafiat või prostitutsiooni (vrd nt lastekirjandus), mitte laste enda ärakasutamist, ja pannud liitma nimetavaliselt: lapsporno(graafia), lapsprostitutsioon. Kui otsida nimetava käände funktsioonide hulgast sobivat, on see vahendi märkimine: laps kui pornograafia või prostitutsiooni vahend. Omastava käände kasuks räägib sobitumine suurde laste-alguliste sõnade sarja ning ka lootus, et lapse pidamine nähtuse sihtrühmaks on teoreetiline. Korpuse andmeil on lasteprostitutsioon suurema sagedusega kui lapsprostitutsioon, kuid enamvähem võrdselt tulevad esile lapsporno(graafia) ja lasteporno(graafia). Seal, kus täiendsõna väljendab sama mis põhisõna, on küll ootuspärane liita nimetavaliselt: lapsprostituut (laps, kes on prostituut, ehk prostituut, kes on laps). Meenutagem, et kuuluvusseose pidamist omastava käände põhifunktsiooniks ja sellest tulenevaid kartusi on olnud näha ka vegansõna puhul.

Osa küsimusi annab taas tunnistust sellest, et rööpvõimaluste esitamine ei pruugi kõhklusi vähendada. Alates 1960. a ÕSist on pidu-liitsõnades 
mööndud rööpselt nii nominatiivset kui ka genitiivset liitumist, selle aluseks on käänamine nii pidu : peo kui ka pidu : pidu. Keelenõuandest on küsitud sõnu pidu-/peokelder, pidu-/peokleit, pidu-/peolaud, pidu-/ peosöök, pidu-/peotort, pidu-/peoõhtu. Kui ülejäänud esinevad ka korpuses variantsena, siis enam-vähem kindla nominatiivse liitumisega on sellest küsitud sõnade reast liitsõna pidusöök. Genitiivse täiendsõnaga hommikuvõimlemise kõrvale tõi ÕS 1976 nominatiivse hommikvõimlemise (vt Kask 1967: 26), korpuses domineerib genitiivne liitumine.

Mõnest küsimusest on koorunud võimalus väljendada täiendsõna vormiga eri sisu, nt kunstfoto 'kunstipärane foto' ja kunstifoto 'foto kunstist', paberileht 'leht paberit' ja paberleht 'ka: paber(aja)leht', palgilõks 'lõks palkide püüdmiseks' ja palklõks 'palkidest lõks', raudtuum 'mingi asja rauast tuum' ja rauatuum 'raua enda tuum', samuti taimtoit 'taimed toiduna' ja taimetoit 'taimedest toit', vesiküte ja veeküte, ólglill 'immortell' ja ôlelill 'Xerochrysum Tzvelev'. Abstraktsema tähendusega sõnades võib aga olla raske piire ajada.

Uusi taust-algulisi liitsõnu moodustades on nii küsijad kui ka vastajad püüdnud orienteeruda selles, kas jutt käib taustal olevatest, tausta puudutavatest või iseloomustavatest nähtustest või hoopis taustast endast. Selle järgi on soovitatud nt nominatiivsena taustandmed, taustdokument, taustinfo(rmatsioon), taustmaterjal, taustmuusika, taustteadmised (andmed, info, muusika jne on taust), genitiivsena aga taustaanalüüs, taustakontroll, taustauuring (objektitähendus), taustaheli, taustalaulja, taustalint, taustatunnus. Mõnes nõuandes on jäänud ühene seisukoht ka võtmata, nt taust-/taustaanalüüs (kas analüüs on taustaks või analüüsitakse tausta?), taust-/taustaandmed, taust-/taustamuusika, taust-/taustamüra, taust-/taustavalgus, taust-/taustategur. ÕSis on taust-liitsõnadest esitatud genitiivse täiendsõnaga taustauuring (objektitähendus), samuti taustabänd, -laulja, -näitleja, mis on ka korpuse andmeil üsna kindel genitiivse liitumise rühm, ning nominatiivsed taustteave, -muusika, -süsteem. Põhisõnade andmed, info(rmatsioon), teave puhul on korpuses siiski näha variantsust, nt pigem nominatiivse täiendsõnaga taustteave (nom 420, gen 199), taustinformatsioon (431/201) ning pigem genitiivsega taustaandmed (116/162), taustainfo (755/2352).

Rohkesti küsimusi on tekitanud lõpp-algulised liitsõnad, kus nominatiivne täiendosa on senise normingu kohaselt olnud seotud tähendusega 'viimane, lõplik, lõpmine' (küsijaile on mh soovitatud sõnu lõppakord, 
-analüüs, -aruanne, -kontsert, -kõne, -peatus, -raport, -vokaal, -üritus) ja genitiivne tähendusega 'lõppu kuuluv, lõpposa' (sajandi lõpukümnendid, vrd sajandi lõppkümnend). ${ }^{7}$ Kasutuses tuleb siiski ette erandeid, nt nimetatakse abituuriumi valdavalt lõpu-, mitte lõppklassiks, seda arvestades on 2013. a ÕSis nominatiivsest täiendsõnast loobutud. Nii keelenõuande vastustes kui ka korpuses on kõikuv, kuid siiski rohkem nominatiivse liitumise poole kalduv lõpp-/lõpukuupäev (1369/932), võrdle ÕSi lõpptähtpäev, mis tuleb ka korpuses esile ainult nominatiivse täiendsõnaga.

Omasõnadegi hulgas on selliseid, mis täiendsõnana kalduvad andma ebareeglipäraseid nominatiivseid liitumisi, nagu $i$-lõpulised kahesilbilised esmavältelised sõnad $k a ̈ s i$, mesi, tuli, vesi, veri, harvemini meri, mägi, uni (Aavik 1914: 15; Kull 1961: 90). Keelenõuandest on selle rühma sõnadest enim küsitud vesi-algulisi, mh vesi-/veevoodi, vesi-/veevõimlemine, vesi-/ veeaeroobika, vesi-/veevann. Liitsõnad veeaeroobika ja veevõimlemine (nagu veepidu, veesport) fikseeris genitiivse liitumisega ÕS 1999, kuid täiendsõna vorm on tekitanud küsimusi ja ka korpuses domineerivad nominatiivse liitumisega vesiaeroobika (kuid siiski ainult genitiivne süvaveeaeroobika) ja vesivõimlemine (nagu vesiroos, vesilennuk). Kasutusandmeid arvestades lisas ÕS 2013 veeaeroobika kõrvale vesiaeroobika ja asendas genitiivse veevõimlemise nominatiivse vesivõimlemisega. Vesi-sõna kalduvus nominatiivselt liituda tuleb ilmekalt esile nt vann-põhisõna puhul, kus ootuspärase genitiivi kõrval (vrd auru-, mulli-, piima-, soola-, vahu-, ôhuvann) näeb korpuses peaaegu niisama palju nominatiivset liitumist (kuid siiski ainult genitiivselt kuumavee-, külmavee-, mineraalveevann). Varasemal ajal on normingut muudetud liitsõna vesi-/veevarustus puhul: 1930. aastate ÕSides (EÕS, Muuk) on veel nominatiivse liitumisega vesivarustus, kuid alates 1960. a ÕSist on kasutajaid suunatud genitiivse veevarustuse poole ${ }^{8}$, ka korpuses domineerib genitiivne täiendsõna.

Amet-liitsõnade pesa on ÕSides olnud ühtlaselt genitiivse liitumisega, kuid sellegi sõna puhul on juba varasemast täheldatud kalduvust ka nominatiivselt liituda. ${ }^{9}$ Keelenõuandest on küsitud mh sõnu ametikiri,

7 Eristuse kujunemise kohta vt Aavik 1914: 20; Raiet 1955: 80.

8 Märksõna vesivarustus on üks väheseid näiteid, kus liitumise seisukohalt ebasoovitatav vorm on 1976. a ÕSis esitatud looksulgudes, 1999. a ÕSis lisandus looksulgudes silmnähtavalt (vt ka Raadik, Mäearu 2020).

9 Aavik (1914: 20) on kõhklemisi pidanud võimalikuks ametühisust, kuid hiljem liigitanud ametasutuse ja ametühingu veaks või liialduseks nominatiivse liitumise 
-koht, -käik, -mees, -post, -ruum, -side, -ühing, korpuses on vähesel määral nominatiivset liitumist näha suurema sagedusega sõnades amet-/ ametiühing, amet-/ametimees, amet-/ametikoht. Üsna samasugune pilt avaneb ravim-liitsõnade puhul, nt vastajaile genitiivsena soovitatud ravimiesitleja, -firma, -grupp, -jäätmed, -teatmik, -uuring, -valik, -viga on ka korpuses valdavalt genitiivse täiendsõnaga, lisaks osa sõnu vähesel määral nominatiivsega, nagu ravim-/ravimifirma, ravim-/ravimiuuring. Muude variantide kõrval hakkab korpusetekstides silma veebilehe aadress raviminfo.ee pro ootuspärane ravimiinfo.ee. Mitut puhku on küsimusi tekitanud ÕSis olev genitiivne ravimivorm (kuuluvusseos: mis vorm on mingile ravimile omane), millele farmaatsias eelistatakse nominatiivset ravimvormi (vt Hinrikus 2001: 15-16, 20).

Sõjandussõnavaras kalduvad nominatiivselt liituma lahing (lahingüksus, -padrun, -moon pro lahinguüksus, -padrun, -moon) ja rännak (rännaküksus, -rivistus pro rännakuüksus, -rivistus) (Kuldnokk 2004: 191), ka keelenõuküsijaile genitiivse täiendsõnaga soovitatud lahing-liitsõnad esinevad korpuses variantsena: lahing-/lahingugrupp 131/2461, lahing-/ lahingukogemus 24/322, lahing-/lahingurelv 109/180, lahing-/lahinguüksus 271/400, lahing-/lahinguülesanne 163/431.

\section{Põhisõna juurde moodustunud sarjad}

Vahenditähendusega täiendsõnade puhul on keelenõuküsijaile enim probleeme valmistanud esikomponentide elekter ja gaas kääne (nt kas elekter- või elektritransport) ning nii oma- kui ka võõrsõnade liitmine põhisõnadele ravi ja teraapia (kas geen- või geeniravi).

Elekter- ja gaas-algulistes liitsõnades on ÕSid alates 1976. aastast järginud põhimõtet, mille kohaselt sobib oskuskeeles vahenditähendusega täiendsõna liita menetluse ja isiku märkimisel - deverbaalsed põhisõnad nominatiivselt (gaaskeevitus, gaaskeevitaja), seadmetes aga genitiivselt (gaasiboiler). Üldkeeles võib tava olla teistsugune. Kui vaadata keelenõust küsitud elekter- ja gaas-liitsõnade esinemust korpuses, on ka menetluste ja isikute rühmas näha genitiivse liitumise ülekaalu: pigem elektrikeevitus, -küte, -ravi, -transport, -valgustus, gaasikeevitus, -keevitaja, -kromatograafia kui elekter- või gaas-, ning üksnes genitiivsena elektrikeevitaja,

alal (Aavik 1936: 25); Riikoja (1962: 621) on toonud murdekeelest nominatiivse täiendsõnaga näiteid ametmees, ametisik, ametvennad, ametasutus. 
gaasilõikus, gaasitehnoloogia, gaasitoide. Seadmenimetustes on nii normingus kui ka korpuses valdav genitiivne täiendsõna, kuid küsijad on siiski kahelnud ka sellistes sõnades, nagu elektriauto, -nuga, -rong, -sõiduk, -tara, gaasigrill, -katel, -kromatograaf.

Põhisõna järgi võib keelenõuküsimustes esile tuua ka väikese kütelõpuliste liitsõnade sarja, kus korpuse andmeil liitub kindlalt nominatiivselt vaid õhkküte (kas tajutakse genitiivse täiendsõna objektilist sisu või on eeskujuks samuti nominatiivsed õhkjahutus, õhksoojuspump). Korduvalt küsitud põrandaküte oli 1999. ja 2006. a ÕSis genitiivse täiendsõnaga, kaks järgmist ÕSi püüdsid erialainimeste soovil teha täiendosa käändel vahet sisuliselt (ÕS 2013: põrandaküte 'köetakse põrandat', põrandküte 'köetakse põranda kaudu') või allkeele järgi (ÕS 2018 lahenduse kohta vt eespool tabel 1). Kuivõrd erinevalt ahjust, kaminast või radiaatorist pole põranda, seina ega lae esmane ülesanne küttekehaks olemine ${ }^{10}$, võiks nende kaudu kütmist ehk siiski tähistada genitiivse täiendsõnaga, piirdudes nominatiiviga vaid otsest vahendit näitavais termineis vesi-, ôhk-, elekterküte jts.

Suures ravi-ja teraapia-lõpuliste liitsõnade sarjas saab nominatiivset ja genitiivset liitumist vaheldades eristada vahenditähendust objektitähendusest, nt loomteraapia 'loomade abil ravimine' ja loomateraapia 'loomade ravimine'. Kui objektitähendus ei ole oluline, nagu sõnades elekter-/elektriravi, tablett-/tabletiravi, võib ka täiendsõna vorm varieeruda. Selle sarja enim küsitud liitsõna on aroom-/aroomiteraapia, mille ÕS on fikseerinud süsteemselt nominatiivsena (korpuses on ülekaalus genitiivne liitumine), seevastu 2018. a ÕSi lisatud geeniteraapia puhul on juba arvestatud üksnes kasutust (korpus ei näita nominatiivset liitumist), ehkki vahendit väljendava täiendsõna nominatiivne liitmine annaks siin selgema tulemuse (nominatiivse liitumisega on ÕSis geeniteraapia seletuses esitatud vaste geenravi). Keelenõuküsijaile on soovitatud nominatiivse täiendsõnaga raviliike aroom-, loom-, lõhn-, ravim-, tsoon-, õisteraapia; elekter-, geen-, hormoon-, beetainterferoon-, koer-, lemmikloom-, lõhn-, mahl-, metadoon-, naer-, osokeriit-, pump-, pung-, püramiid-, tablett-, taim-, tants-, termiit-, botulismitoksiin-, tramadool-, tüvirakk-, C-vitamiin-, õisravi.

Ainet või materjali tähistava täiendosaga liitsõnadest on keelenõuandest küsitud mõnd roog-, siid-, sulg-liitsõna (roog-/rookatus, siid-/

${ }^{10}$ Argo Mundi meilinõuanne 8. IV 2013. 
siidikangas, siid-/siidilõng, siid-/siidiriie, siid-/siidiöösärk, sulg-/sulejope, pilliroog-/pillirookepp, udusulg-/udusulepadi, udusulg-/udusuletekk, puuvill-/puuvillaöösärk, puuvill-/puuvillariie), milletaoliste kohta võib ka ÕSist leida soovitusi, kuid võrreldes elekter- ja gaas-liitsõnu puudutavatega on need üksikküsimused. Põhisõna järgi tõusevad küsimustes esile kaks sarja, toode- ja jääde-lõpulised liitsõnad, kus täiendsõna vormi vaheldades saab vajaduse korral väljendada eri sisu, nt paber-, puittoode 'toode on paber, puit' ja paberi-, puidutoode 'paberist, puidust toode', paber-, plast-, vaskjäätmed 'paber, plast, vask jäätmetena' ja paberi-, plasti-, vasejäätmed 'paberist, plastist, vasest jäätmed'. Selline vahetegemine saab toetuda põhimõttele, mille kohaselt eelistatakse ainesõnades nominatiivset liitumist sel korral, kui täiendsõna määrab põhisõna olemust, on liitsõna sisuliseks keskmeks, genitiivi aga siis, kui üks liitsõna osiseks olev sõna teisest sõltub, liitsõna põhisisu kannab täiendosa (Kask 1967: 15; EKK: 359). Toote-sarja nominatiivse ja genitiivse liitumise juhised esitati 1970. aastal Emakeele Seltsi keeletoimkonna soovituskirjas kaubanduskeele parandamiseks (Kull 1971: 259).

Oskuskeele, st mõistesüsteemi poolt vaadates on oluline põhisõna juurde moodustuva sarja ühtne vormistus, nt kütte-, raviliigid. Üldkeeles ei ole sellist mõistesüsteemi tunda, sõnad tulevad ette üksikult, vaadatakse pigem täiendsõna sarju või üht juhuslikku analoogi.

\section{Kokkuvõtteks}

Nominatiivse ja genitiivse liitumise senises normimises võib soovituste laadi järgi esile tuua kaks rühma: terminid vs. üldkeele sõnad ning võõrsõnalise esikomponendiga liitsõnad. Esimeste puhul on ÕSides püütud anda selgeid soovitusi, viidates märgenditega kõnekeelne või argikeelne või kommentaaridega üld- ja oskuskeele erinevale liitumistavale, teisel juhul on otsestest soovitustest hoidutud, norming tuleb välja lugeda ÕSi valitud sõnakuju(de)st.

Võõrsõnaliste esikomponentide hulgas on nii vanemaid (nt kontroll, kontsert, treening) kui ka uuemaid (nt liising, vegan), lisaks on vanemaid võõrsõnu, mis on hakanud andma rohkesti uusi liitsõnu just viimastel aastakümnetel (nt ekspert, projekt, reklaam, kuller, proviisor). Kui teatavate vanemate võõrsõnade puhul on ka ÕSi fikseeringus enamasti aktsepteeritud kasutuses levinud, kuid eesti liitumisreeglitest erinevat 
liitumist, esitades ootuspärase genitiivi asemel nominatiivse täiendsõna (nt kontsert-, kontroll-liitsõnad) või rööpselt nii nominatiivse kui ka genitiivse (nt remont-/remonditöö), siis uuemate liitsõnade normingus on sagedamini märgata taotlust allutada võõrsõnaline esikomponent eesti liitumismallidele. Oma osa on siin kindlasti olnud ka kaalutlustel, et varasem sekkumine võiks anda liitumismalli muutmise seisukohalt paremaid tulemusi, kuid see ei pruugi alati nii olla. Korpuseuuringu andmeil võib nt liising-liitsõnade puhul tõesti rääkida kalduvusest liituda pigem genitiivselt, eriti kui võrrelda nt teise ing-lõpulise sõna ehk treeninguga, mille puhul süveneb nominatiivse liitumise tendents. Seevastu nt ekspert-ja vegan-algulised liitsõnad, millest esimesed hakkasid keeles laiemalt levima 1990. aastatel ja teised 2010ndatel, on säilitanud kalduvuse liituda nominatiivselt, mida ei ole takistanud ka nt konsonandikobarate teke (vrd ekspertgrupp või eksperdigrupp) ning kus vaid mõnel määral ilmneb soovituslike genitiivide mõju. Seesuguste sõnade puhul tuleks senisest enam arvestada korpuse andmetega, aktsepteerides vajaduse korral nominatiivse liitumise domineerimist või mööndes nominatiivsegenitiivse liitumisviisi kõrvuti esinemist. Keelekasutaja kõhklustest võõrsõnalise esikomponendi liitmisel annab tunnistust Eesti Keele Instituudi keelenõuandmebaas, kus võõrsõnalist täiendsõna puudutavad küsimused on laias laastus kaks korda sagedasemad kui omasõnalise täiendsõna kohta käivad. Võõrsõnaküsimuste edetabeli tipus on valdavalt sama tüüpi sõnad, mille nominatiivse liitumise kalduvusele on osutanud varasemad uuringud.

Oskuskeelekorpuste nappuse tõttu ei ole praegu veel võimalik uurida, mil määral järgitakse nominatiivse ja genitiivse liitumise põhimõtteid oskustekstides. Sõnamoodustuse uurijad on olnud enam-vähem ühel meelel selles, et oskuskeel vajab võimalust väljendada täiendsõna eri vormi kaudu erinevat sisu, näiteks selleks, et teha vahet vahendi- ja objektisuhtel (masinpesu ja masinapesu, õhkjahutus ja õhujahutus). Iseküsimus on, kas seda arvestatakse ka nt neil juhtudel, nagu elekterravi ja elektriravi, gaaskeevitus ja gaasikeevitus, kus nominatiivil ja genitiivil ei ole sisulist tähendusvahet. Üldkeelekorpusest võib leida näiteid, et ka sõnades, kus täiendsõna kääne võiks väljendada eri tähendust, ei kajastu see tingimata tegelikus tarvituses, nt on vahendisõnade reeglipärase nominatiivse täiendsõnaga geenravi ja geenteraapia asemel korpuses valdavad genitiivse täiendsõnaga geeniravi ja geeniteraapia. 
Tõenäoliselt ei mõtle keelekasutaja sellele, kas geene saab ravida või ei, vaid võtab eeskujuks mõne muu üldkeelse genitiivse ravi-sõna (olgu või elektriravi).

ÕSid on alates 1976. aastast aktsepteerinud üld- ja oskuskeele erinevat tava, vormides oma soovitusi aegamööda selgemasse sõnastusse. Keelenõuküsimused näitavad siiski, et kahtluskohad ei pruugi ajast aega olla just ühed ja needsamad. On loomulik, et sitsrätiku, kanepnööri või pilbaskatuse asemel huvitavad tänapäeva küsijat hoopis rohkem pistikhübriid, tekstsõnum või pilveteenus. Keelenõuandele esitatavate küsimuste hulgas on sõnu, mida pole sõnastikes fikseeritud või mille kohta vähemalt küsimuse esitamise hetkel ei ole võtta tuge ka korpusest. Samavõrd kui seisukohavõtte ammuste vaidlusteemade asjus on liitumisnõu vajajad järginud ka põhimõtteid, millele toetuda päris uute oskussõnade loomisel.

\section{Kirjandus}

Aavik, Johannes 1914 [kaanel 1915]. Nominatiivsed liitumised. Tartu: Eesti Kirjanduse Seltsi Kirjastus.

Aavik, Johannes 1936. Eesti õigekeelsuse õpik ja grammatika. Tartu: NoorEesti Kirjastus.

EKG = Mati Erelt, Reet Kasik, Helle Metslang, Henno Rajandi, Kristiina Ross, Henn Saari, Kaja Tael, Silvi Vare 1995. Eesti keele grammatika I. Morfoloogia. Sõnamoodustus. Peatoim. Mati Erelt, toim. Tiiu Erelt, Henn Saari, Ülle Viks. Tallinn: Eesti Teaduste Akadeemia Eesti Keele Instituut.

EKI ühendsõnastik 2021. Sõnaveeb 2021. https://sonaveeb.ee.

EKK = Mati Erelt, Tiiu Erelt, Kristiina Ross 2020. Eesti keele käsiraamat. Uuendatud väljaanne. Eesti Keele Instituut. Tallinn: EKSA.

Erelt, Tiiu 1976. Keelenõuanne Tallinnas. Sõna ja tema kuju (2). - Keel ja Kirjandus 12, 717-724.

Erelt, Tiiu 2003. ÕS-i toimetaja selgitab. - Keel ja Kirjandus 6, 448-460.

Erelt, Tiiu 2007. Terminiõpetus. Tartu: Tartu Ülikooli Kirjastus.

Erelt jt 1971 = Tiiu Erelt, Rein Kull, Valve Põlma, Erich Raiet, Kristjan Torop 1971. Keelekorraldus ja liitsõnad. - Keel ja Kirjandus 6, 367-374.

EÕS = Eesti õigekeelsuse-sõnaraamat I-III, 1925-1937. „Eesti keele õigekirjutuse-sõnaraamatu“ II täiendatud ja parandatud trükk. Tartu: Eesti Kirjanduse Seltsi Kirjastus.

Hinrikus, Toivo 2001. Farmaatsia oskussõnavara arenemisest. - Emakeele Seltsi aastaraamat 46 (2000). Peatoim. Mati Erelt. Eesti Teaduste Akadeemia Emakeele Selts. Tartu, 12-24. 
Jürgenson, Leo 1968. Tehnika keel vajab suuremat selgust sõnatuletuses. Emakeele Seltsi aastaraamat 13 (1967). Eesti NSV Teaduste Akadeemia Emakeele Selts. Tallinn: Eesti Raamat, 183-188.

Kasik, Reet 2015. Sõnamoodustus. (= Eesti keele varamu I.) Tartu: Tartu Ülikooli Kirjastus.

Kask, Arnold 1967. Eesti keele grammatika III. 1. vihik. Liitsõnad ja sõnade liitumisviisid eesti keeles. Tartu: Tartu Riiklik Ülikool, eesti keele kateeder.

Kolehmainen, Taru 2011. Nominatiivi vai genetiivi yhdyssanan alussa? Kielenhuollon historiaa. - Kielikello 2. https://www.kielikello.fi.

Kuldnokk, Karen 2004. Sõjandusterminite vorm. Toimiv keel II. Töid rakenduslingvistika alalt. Toim. Maria-Maren Sepper, Jane Lepasaar. Koost. Helle Metslang. (= Tallinna Pedagoogikaülikooli eesti filoloogia osakonna toimetised 3.) Tallinna Pedagoogikaülikool, Eesti Keele Instituut. Tallinn: TPÜ Kirjastus, 185-194.

Kull, Rein 1961. Keelenorm ja teadlik keeletarvitus. (Järg.) - Keel ja Kirjandus 2, 89-100.

Kull, Rein 1966. Vormitüübi mõju võõrsõnalise esikomponendi liitumisele. Keel ja Kirjandus 5, 284-294.

Kull, Rein 1970. Quo vadit eesti õigekeelsussõnaraamat. Sõnamoodustuse sihiseadeid. - Keel ja Kirjandus 7, 390-404.

Kull, Rein 1971. Emakeele Seltsi keeletoimkonna otsuseid ja soovitusi. - Emakeele Seltsi aastaraamat 17 (1971). Eesti NSV Teaduste Akadeemia Emakeele Selts. Tallinn: Eesti Raamat, 251-261.

Kull, Rein 1985. Kirjakeelest ja selle korraldamisest. („Kirjakeele korraldus nüüd ja praegu“.) - Keel ja Kirjandus 12, 705-713.

Leibak, Eerik 2001. Maailma lindude eestikeelsetest nimetustest. - Emakeele Seltsi aastaraamat 46 (2000). Peatoim. Mati Erelt. Eesti Teaduste Akadeemia Emakeele Selts. Tartu, 37-45.

Liivaku, Uno 2008. Oma omastavaga, võõras võõrastavaga. - Õiguskeel 2. https://www.just.ee/sites/www.just.ee/files/uno_liivaku._oma_omastavaga_vooras_voorastavaga.pdf.

Muuk, Elmar 1940. Väike õigekeelsus-sõnaraamat. 7. trükk. Tartu: Eesti Kirjanduse Selts.

Muuk, EImar, Mihkel Tedre 1931. Lühike eesti keeleõpetus II. 2. trükk. Tartu.

Mäearu, Sirje 2015. Kas vanillsuhkur või vanillisuhkur? - Keelenõuanne soovitab 5. Koost. ja toim. Maire Raadik. Eesti Keele Instituut. Tallinn: Eesti Keele Sihtasutus, 130-134.

Mäearu, Sirje 2016. $s$-lõpuliste nimisõnade liitumisest. - Oma Keel 2, 70-81.

Nurm, Ernst 1971. Mõnda liitsõnadest. Väiteid ja vastuväiteid. - Keel ja Kirjandus 3, 168-175.

Raadik, Maire 2005. Panganduskeel. Tallinn: Eesti Keele Sihtasutus. 
Raadik, Maire, Sirje Mäearu 2020. Silma nähes, kõrva kuuldes, käe katsudes. - Keelenõuanne soovitab 6. Koost. ja toim. Maire Raadik. Tallinn: EKSA, 122-123.

Raiet, Erich 1955. Õigekeelsuse küsimusi nimetavalise ja omastavalise liitumise alalt. - Emakeele Seltsi aastaraamat I. Eesti NSV Teaduste Akadeemia Emakeele Selts. Tallinn: Eesti Riiklik Kirjastus, 77-80.

Riikoja Elli 1956. Kirjakeele ja rahvakeele vahekorrast mõningates nominatiivse liitumise rühmades. - Keele ja Kirjanduse Instituudi uurimused I. Eesti NSV Teaduste Akadeemia. Tallinn: Eesti Riiklik Kirjastus, 88-104.

Riikoja, Elli 1958. Kehaliiget ja abinõu märkivate sõnade liitumisest. - Keel ja Kirjandus 4-5, 280-289.

Riikoja, Elli 1960. Eesti keele nimisõnade nominatiivse liitumise reeglite rahvakeelne alus. Käsikirjaline kandidaadiväitekiri. Tallinn.

Riikoja, Elli 1962. Nimisõnade nominatiivset ja genitiivset liitumist mõjustavaid tegureid. - Keel ja Kirjandus 10, 612-622.

Tauli, Valter 1968. Keelekorralduse alused. (= Eesti Teadusliku Seltsi Rootsis väljaanne nr 4.) Uppsala: Kirjastus Vaba Eesti.

Tauli, Valter 1972. Eesti grammatika I. Hääliku-, vormi- ja sõnaõpetus. Uppsala.

Vare, Silvi 2001. Üldkeele ja oskuskeele nihestunud suhe. - Keel ja Kirjandus 7, 455-472.

Veski, J. V. 1913. Eesti kirjakeele edasiarendamise-teedest. - Voog I. (= Eestimaa Rahvahariduse-Seltsi Kirjanduse-Haruseltsi toimetused nr 15.) Tallinn: Teaduse Kirjastus, 99-120.

Veski, J. V. 1914. Eesti keele uuendamise asjus. (Vastukaaluks J. Aaviku mõtteavaldustele.) - Eesti Kirjandus IX, 182-184.

Veski, J. V. 1954. Kriitilisi märkmeid „Väikese õigekeelsuse sõnaraamatu“ kohta. - Edasi 20. IV.

Veski, J. V. 1957. Ääremärkusi nimisõnade liitmise kohta eesti kirjakeeles. - Emakeele Seltsi aastaraamat III. Eesti NSV Teaduste Akadeemia Emakeele Selts. Tallinn: Eesti Riiklik Kirjastus, 21-35.

Väike õigekeelsuse sõnaraamat 1953. Eesti NSV Teaduste Akadeemia Keele ja Kirjanduse Instituut. Tallinn: Eesti Riiklik Kirjastus.

ÕS 1960 = Õigekeelsuse sõnaraamat 1960. Toim. Ernst Nurm, Erich Raiet, Magnus Kindlam. Eesti NSV Teaduste Akadeemia Keele ja Kirjanduse Instituut. Tallinn: Eesti Riiklik Kirjastus.

ÕS 1976 = Õigekeelsussõnaraamat 1976. 3. trükk. Toim. Rein Kull, Erich Raiet.

Eesti NSV Teaduste Akadeemia Keele ja Kirjanduse Instituut. Tallinn: Valgus, 1980.

ÕS $1999=$ Eesti keele sõnaraamat ÕS 1999. Toim. Tiiu Erelt. Koost. Tiina Leemets, Sirje Mäearu, Maire Raadik, Tiiu Erelt. Eesti Keele Instituut. Tallinn: Eesti Keele Sihtasutus. 
ÕS $2006=$ Eesti õigekeelsussõnaraamat ÕS 2006. Toim. Tiiu Erelt. Koost. Tiiu Erelt, Tiina Leemets, Sirje Mäearu, Maire Raadik. Eesti Keele Instituut. Tallinn: Eesti Keele Sihtasutus. http://www.eki.ee/dict/qs2006.

ÕS 2013 = Eesti õigekeelsussõnaraamat ÕS 2013. Toim. Maire Raadik. Koost. Tiiu Erelt, Tiina Leemets, Sirje Mäearu, Maire Raadik. Eesti Keele Instituut. Tallinn: Eesti Keele Sihtasutus. http://www.eki.ee/dict/qs2013. ÕS 2018 = Eesti õigekeelsussõnaraamat ÕS 2018. Toim. Maire Raadik. Koost. Tiiu Erelt, Tiina Leemets, Sirje Mäearu, Maire Raadik. Eesti Keele Instituut. Tallinn: EKSA. https://www.eki.ee/dict/qs.

\section{Andmekogud}

Digar $=$ Rahvusraamatukogu digitaalarhiiv Digar. https://www.digar.ee/arhiiv.

Eesti keele ühendkorpus 2019 = Estonian National Corpus 2019, Estonian NC 2019. https://www.sketchengine.eu/estonian-national-corpus/.

Keelenõuandmebaas $=$ Eesti Keele Instituudi keelenõuandmebaas. https:// keeleabi.eki.ee/?leht $=8 \& \mathrm{id}=132$. 


\title{
Borrowing, analogy and semantics in compound word formation
}

\author{
MAIRE RAADIK
}

The article compares nominative and genitive compounding in Estonian compound nouns. The analysis is based on the nearly 3,300 questions on the subject, which have been filed in the Language Advice database of the Institute of the Estonian Language from 1995-2020. The database material is juxtaposed with the relevant data drawn from the Sketch Engine corpus Estonian National Corpus 2019. A closer look is taken at the compounding of the first components (borrowed or genuine) in the compound nouns. The analysis concerns certain bigger word groups as well as some more problematic individual words, following the emergence and evolution of compounding rules and examining, based on user data, how the rules have changed by the time the compound word makes its way to the orthological dictionary, specifically on the example of compound nouns where the attributive part has an instrumental meaning.

The group of foreign words used as first components contain both older (e.g. kontroll 'control', kontsert 'concert', treening 'workout') and newer words (e.g. liising 'leasing', vegan). In addition, there are some older loanwords (e.g. ekspert 'expert', projekt 'project', kuller 'courier') which have only become productive in compounding over the last decades. It turns out that some of the older foreign words used as first components have been included in the dictionary despite their deviant compounding (mostly accepted in use, though), where the attributive word occurs either in the nominative case instead of the expected genitive (e.g. compounds beginning with kontsert- or kontroll-) or where both nominative and genitive compounding are used in parallel. In newer compounds, however, both the orthological dictionary and the answers provided by the Language Advice reveal a tendency to subject the first component of foreign origin to Estonian compounding rules. One of the reasons may lie in the consideration that a "nip in the bud" would probably foster the victory of the Estonian pattern of compounding, but this need not always be the case. According to the corpus study, the compounds beginning with liising-, for example, do obey the Estonian rule of genitive compounding (not, however, the tennis-compounds, despite their similar structure), whereas most of the compounds beginning with, e.g., ekspert- or vegan- have stuck to their foreign bias towards nominative compounding, even if it leads to the formation of consonant clusters (like in ekspertgrupp vs eksperdigrupp). 
Language users hesitations in compounding are reflected in the queries submitted to the Language Advice database, where questions concerning attributive words of foreign origin are about twice as frequent as those concerning genuine ones.

Keywords: compound noun, nominative and genitive compounding, special language, general language, language planning, orthological dictionary

Maire Raadik

Eesti Keele Instituut

Roosikrantsi 6

10119 Tallinn

maire.raadik@eki.ee 